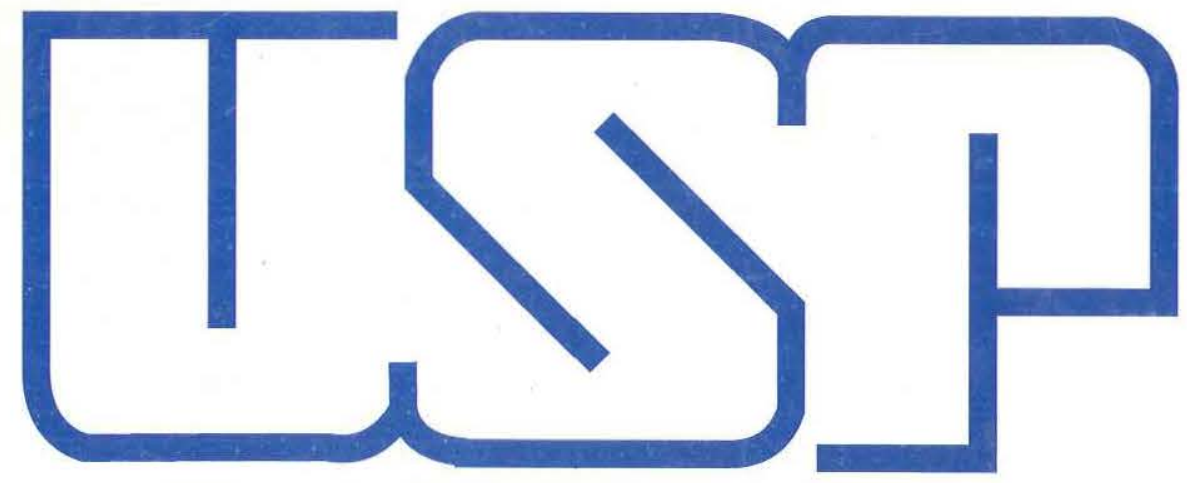

Projeto e Adaptação de Uma Máquina

De Ensaio de Impacto para Ossos Longos de Animais de Pequeno e Médio Porte

Autor: Ricardo Marinzeck Santos

Orientador: Prof. Dr. José B. Portugal Paulin

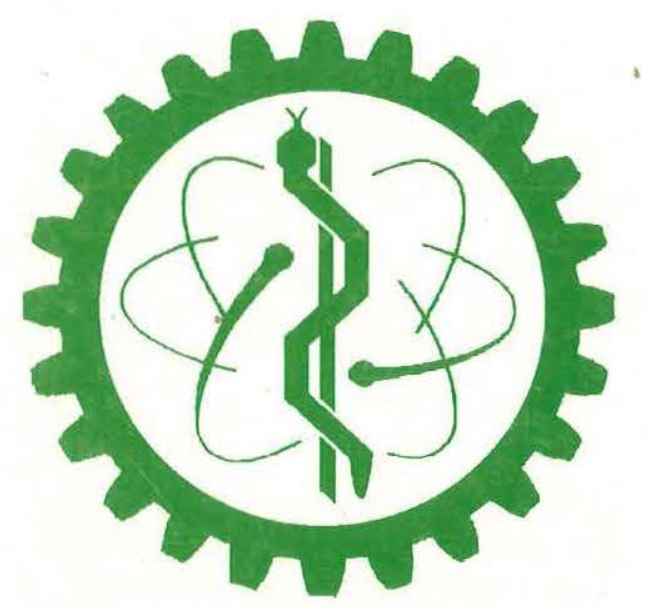

B I O E N G EN H AR IA

USP

Curso de Pós-Graduação Interunidades Bioengenharia

Escola de Engenharia de São Carlos

Faculdade de Medicina de Ribeirão Preto

Instituto de Química de São Carlos 


\title{
PROJETO E ADAPTAÇÃO DE UMA MÁQUINA DE ENSAIO DE IMPACTO PARA OSSOS LONGOS DE ANIMAIS DE PEQUENO E MÉDIO PORTE
}

\author{
Ricardo Marinzeck Santos
}

\begin{abstract}
Dissertação apresentada ao Curso de Pós-Graduação Interunidades Bioengenharia - USP ( Escola de Engenharia de São Carlos / Faculdade de Medicina de Ribeirão Preto / Instituto de Química de São Carlos), como parte dos requisitos para obtenção do título de Mestre em Bioengenharia.
\end{abstract}

ORIENTADOR: Prof. Dr. José Baptista Portugal Paulin

Ribeirão Preto

1999 
$\frac{\text { Cisss. TESE-EESC }}{\text { Gutt. } \frac{5175}{\text { Tombo. T0269199 }}}$

Ficha catalográfica preparada pela Seção de Tratamento da Informaçăo do Serviço de Biblioteca - EESC/USP

Santos, Ricardo Marinzeck

Projeto e adaptação de máquina de ensaio de impacto para ossos longos de animais de pequeno e médio porte / Ricardo Marinzeck Santos. -- São Carlos, 1999.

Dissertação (Mestrado) -- Escola de Engenharia de São Carlos/Faculdade de Medicina de Ribeirão Preto/Instituto de Química de São Carlos-Universidade de São Paulo, 1999. Área Interunidades: Bioengenharia.

Orientador: Prof. Dr. José Baptista Portugal Paulin.

1. Máquina de impacto. 2. Ossos longos.

3. Ensaio de impacto. 4. Ensaio dinâmico. I. Título. 


\section{Universidade de São Paulo}

Curso de Pós-Graduação Interunidades Bioengenharia

Escola de Engenharia de São Carlos

Faculdade de Medicina de Ribeirão Prêto

Instituto de Química de São Carlos

Av. Dr. Carlos Botelho, 1465 - C.P. 359 - 13560)-970 - São Carlos - SP - BRASIL,

Tel. (016) 273-9585 Fax:(016) 273-9586 Fimail: bioeng@sc.usp.br

MEMBROS DA COMISSÃO JULGADORA DA DISSERTAÇÃO DE MESTRADO DO ALUNO RICARDO MARINZECK SANTOS APRESENTADA AO CURSO DE PÓS-GRADUAÇÃO INTERUNIDADES BIOENGENHARIA EESC/FMRP/IQSCUSP, EM 20/07/1999.
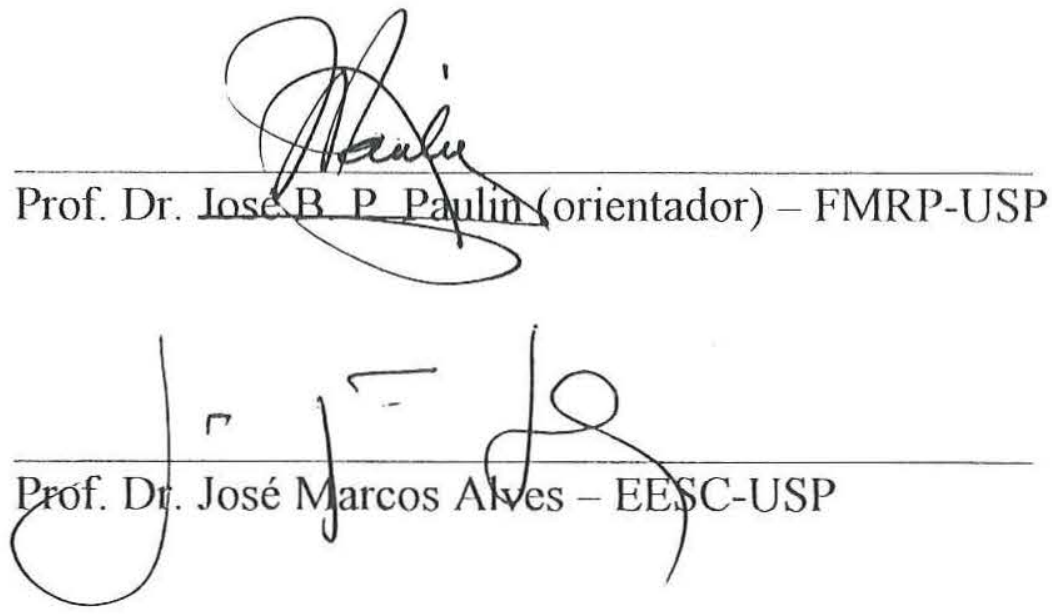

Prof. Dr. Edgard E. Engel - HCFMRP-USP 
Aos meus pais, esposa e filho,

por acreditarem em mim e pelos momentos de ausência. 


\section{Agradecimentos}

Ao Prof. Dr. José Baptista Portugal Paulin, pelo incentivo, ensinamentos, dedicação, amizade e confiança em mim depositada.

Ao Dr. Antônio Carlos Shimano, pelo incentivo, auxílio tecnológico e amizade.

Aos funcionários do Laboratório de Bioengenharia da FMRP - USP, Carlos Alberto Moro, Francisco C. Mazzocato e Luis Henrique A. Pereira, pela paciência, dedicação e amizade.

Aos docentes e funcionários do Laboratório de Bioengenharia / SMM / EESC USP, pela oportunidade de realizar este trabalho.

Ao Prof. Dr. Dirceu Spinelli e Dr. Alberto Cury Nassour, do Departamento de Engenharia de Materiais, Aeronáutica e Automobilística da EESC - USP, pelo acesso a este Departamento, orientações e contribuições tecnológicas.

Aos funcionários da Ofícina Mecânica de Precisão da Prefeitura do Campus da USP de Ribeirão Preto, pela colaboração na confecção da máquina objeto deste trabalho e amizade demonstrada. Ao funcionário Sr. Otávio Terra, pela dedicação, habilidade, capacidade e amizade. 


\section{SUMÁRIO ${ }^{1}$}

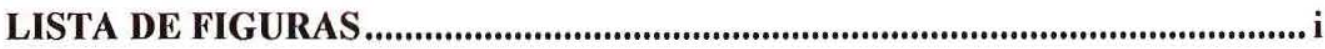

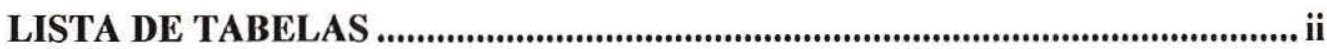

LISTA DE ABREVIATURAS E SIGLAS ............................................................. iii

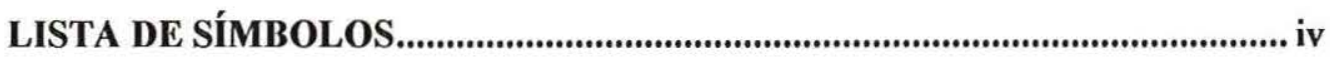

RESUMO

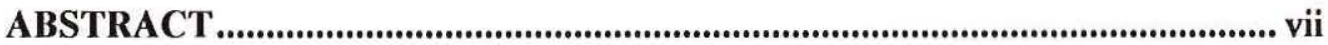

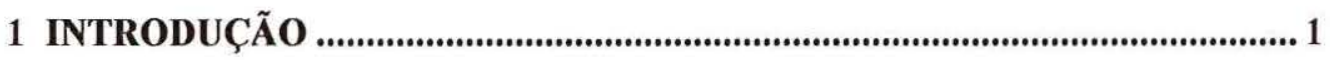

1.1 PROPRIEDADE MECÂNICA DOS OSSOS …............................................. 2

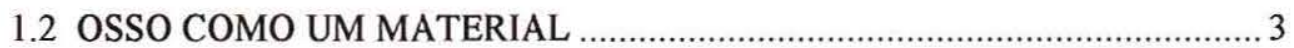

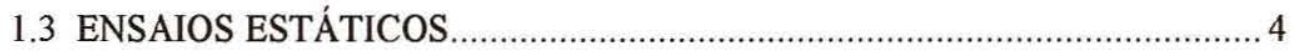

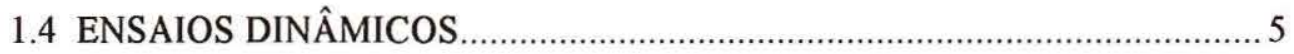

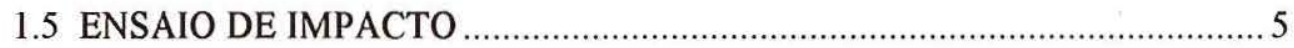

1.5.1 Ensaio de Impacto em Corpos de Prova Entalhados ....................................... 6

1.5.2 Procedimentos Experimentais ............................................................... 7

1.5.3 Ensaio de Impacto em Materiais Biológicos........................................... 12

2 OBJETIVO

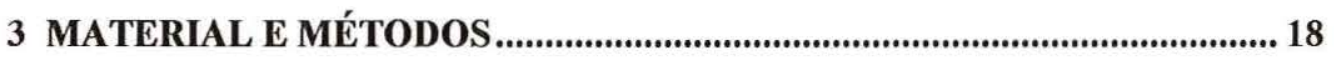

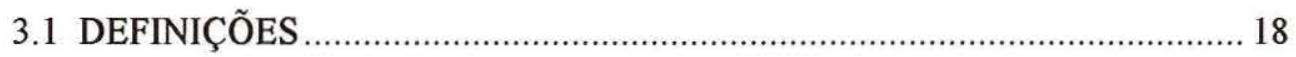

${ }^{1}$ Dissertação elaborada segundo as normas para confecção de teses da EESC - USP $2^{\mathrm{a}}$ ed. 
3.2.1 Confecção da escala graduada

3.2.2 Verificação do alinhamento das peças da máquina

3.2.3 Determinação da aceleração da gravidade

3.2.4 Determinação da velocidade de impacto 24

3.2.5 Energia absorvida. 25

3.3 TESTE DA MÁQUINA DE ENSAIO DE IMPACTO. 26

3.3.1 Teste para corpos de prova padrão 26

3.3.2 Teste para material biológico 27

4 RESULTADOS 28

4.1 ENSAIOS DE AFERIÇÃO DA MÁQUINA DE ENSAIO DE IMPACTO .... 28

4.1.1 Corpos de prova padrão em alumínio 28

4.1.2 Corpos de prova padrão em latão 29

4.1.3 Material biológico 30

5 DISCUSSÃo 31

6 CONCLUSÃo 34

7 SUGESTÕES PARA FUTUROS TRABALHOS 35

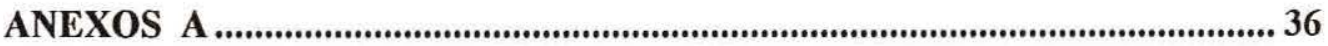

ANEXOS B 43 


\section{LISTA DE FIGURAS}

FIGURA 1.1 - CORPOS DE PROVA RECOMENDADOS PELAS NORMAS DIN, ASTM E ABNT PARA ENSAIO DE IMPACTO E LOCAL DE IMPACTO DO MARTELO. 6

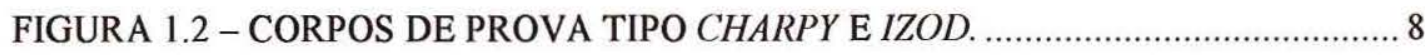

FIGURA 1.3 - MÁQUINA DE IMPACTO TIPO CHARPY. ........................................... 9

FIGURA 1.4 - CONDIÇÕES DO ENSAIO DE IMPACTO …......................................... 10

FIGURA 3.1 - DETALHAMENTO CONSTRUTIVO DA MÁQUINA DE IMPACTO

PARA ENSAIOS DE OSSOS LONGOS, COM MARTELO EM POSIÇÃO DE

DESCANSO. A - BASE DE SUSTENTAÇÃO DE TODA A ESTRUTURA.

B - CANTONEIRAS. C - ESTRUTURAS LATERAIS. D - SUPORTES

LATERAIS. E - DISCO DO MARTELO

FIGURA 3.2 - DETALHAMENTO DOS APOIOS (A) E SUPORTES (B) DO CORPO DE PROVA. 21

FIGURA 3.3 - FORÇAS ATUANTES SOBRE UM PÊNDULO SIMPLES. A

VELOCIDADE NO MOMENTO DO IMPACTO PODE SER DETERMINADA PELA LEI DA CONSERVAÇÃO DA ENERGIA (3) 


\section{LISTA DE TABELAS}

TABELA 3.1 - RELAÇÃO DOS MATERIAIS UTILIZADOS NA CONSTRUÇÃO DA

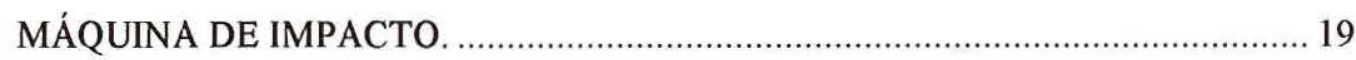

TABELA 4.1 - MÉDIAS E DESVIOS PADRÃO DAS ENERGIAS ABSORVIDAS PELOS CORPOS DE PROVA.

TABELA 4.2 - VALORES DAS ENERGIAS ABSORVIDAS PELAS TÍBIAS, DIREITAS E ESQUERDAS, NO ENSAIO DE IMPACTO REALIZADO NA MÁQUINA DE ENSAIO DE IMPACTO (MEI - 50). 30

TABELA 5.1 - DESVIOS PERCENTUAIS DAS MÁQUINAS DE IMPACTO PARA OS CORPOS DE PROVA DE ALUMÍNIO E LATÃO 


\section{LISTA DE ABREVIATURAS E SIGLAS}

$\begin{array}{ll}\text { ABNT } & - \text { Associação Brasileira de Normas Técnicas } \\ \text { ASTM } & - \text { American Society for Testing and Materials } \\ \text { CP } & - \text { Corpo de prova } \\ \text { DIN } & - \text { Deutsches Institut für Normung } \\ \text { DP } & - \text { Desvio Padrão } \\ \text { EESC } & - \text { Escola de Engenharia de São Carlos } \\ \text { EN } & - \text { Europäische Norm } \\ \text { FMRP } & - \text { Faculdade de Medicina de Ribeirão Preto } \\ \text { IQSC } & - \text { Instituto de Química de São Carlos } \\ \text { MEI } & - \text { Máquina de Ensaio de Impacto } \\ \text { SMM } & - \text { Departamento de Engenharia de Materiais, Aeronáutica e Automobilística } \\ \text { USP } & - \text { Universidade de São Paulo }\end{array}$




\section{LISTA DE SÍMBOLOS}

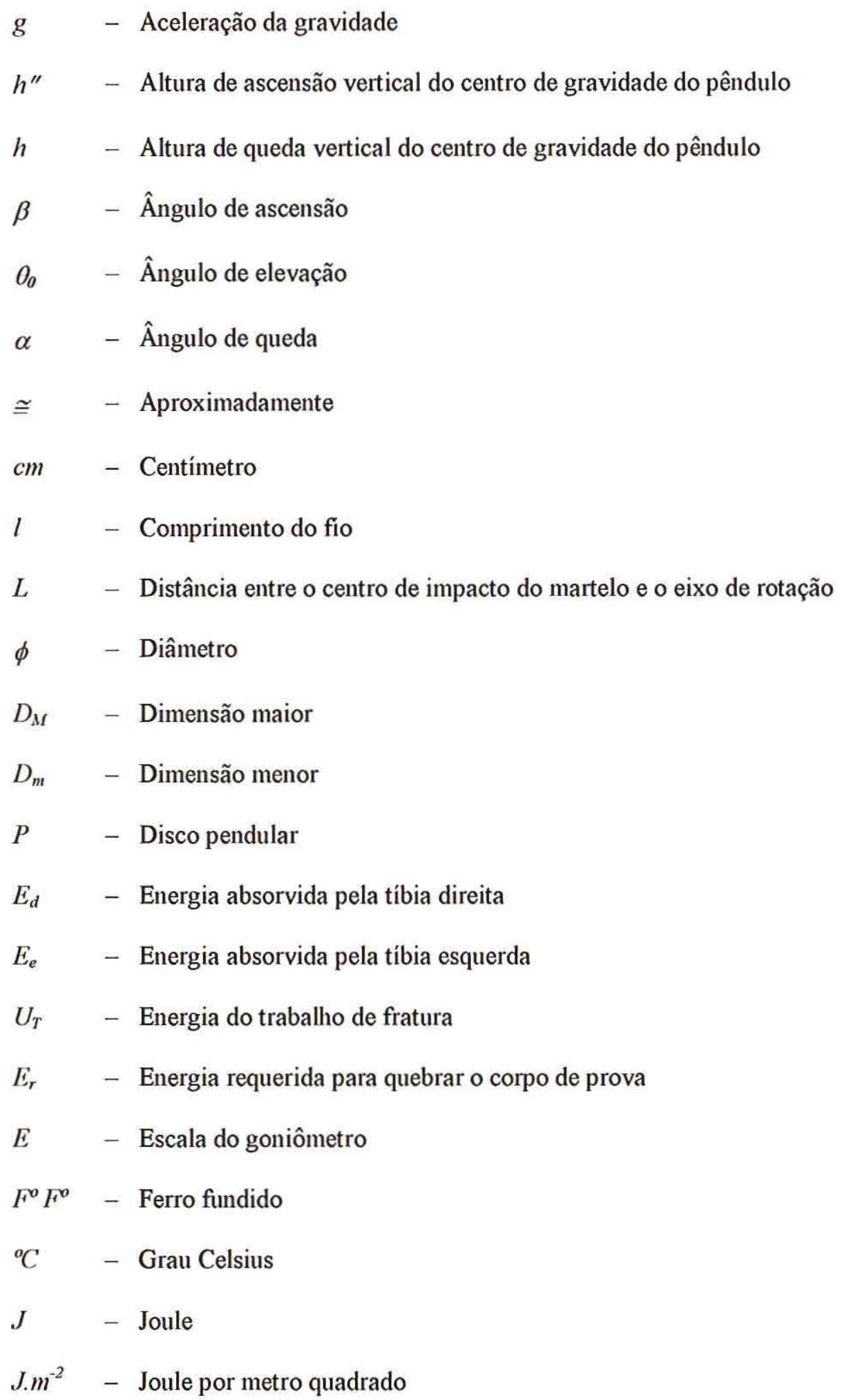




$$
\begin{aligned}
& \begin{array}{l}
J \\
-
\end{array} \\
& J \cdot m^{-2} \text { - Joule por metro quadrado } \\
& \text { lb - Libra } \\
& m \quad \text { - Massa do pêndulo } \\
& m \quad-\text { Metro } \\
& m / s \quad \text { - Metro por segundo } \\
& \mathrm{mm} \text { - Milímetro } \\
& N^{o} \quad-\text { Número } \\
& T \text { - Período de oscilação } \\
& f t / s \quad-\text { Pés por segundo } \\
& \text { W } \quad \text { - Peso do corpo } \\
& \text { " - Polegada (quando colocada após medida) } \\
& N \quad \text { - Ponteiro indicador } \\
& \text { kgf.cm - Quilograma-força centímetro } \\
& k N \text { - Quilonewton } \\
& r \quad-\text { Resolução do indicador } \\
& v \quad-\text { Velocidade de impacto }
\end{aligned}
$$




\section{RESUMO}

SANTOS, R. M. (1999). PROJETO E ADAPTAÇÃO DE MÁQUINA DE ENSAIO DE IMPACTO PARA OSSOS LONGOS DE ANIMAIS DE PEQUENO E MÉDIO PORTE. Ribeirão Preto, 1999. 57p. Dissertação (Mestrado) - Curso de Pós-Graduação Interunidades Bioengenharia - USP (Escola de Engenharia de São Carlos / Faculdade de Medicina de Ribeirão Preto / Instituto de Química de São Carlos).

As fraturas dos ossos longos são geralmente provocadas por esforços dinâmicos de impacto (choque). $\mathrm{O}$ esclarecimento do comportamento de ossos submetidos a testes controlados de impacto pode representar um aprofundamento no conhecimento geral sobre as questões que envolvem a ocorrência das fraturas. Os testes de impacto são, de modo geral, realizados por meio de uma máquina especificamente desenvolvida, provida de um martelo pendular que incide sobre corpos de prova do material testado. Porém, as máquinas de impacto disponíveis no mercado são projetadas para ensaiar materiais com dimensões definidas de acordo com a norma relativa ao tipo de material, que não são adaptadas para materiais biológicos. Os materiais biológicos são em geral anisotrópicos, o que impede a confeç̧ão de corpos de prova com formas e dimensões rigorosamente padronizadas, como acontece com os materiais não biológicos. Desta forma, uma máquina de ensaio de impacto para materiais biológicos deve ser, necessariamente, especificamente desenvolvida para essa finalidade, com a principal característica de que os apoios dos corpos de prova possam ser mudados de forma e posição conforme as necessidades de cada material em teste.

Foi o objetivo deste trabalho, projetar, construir e testar, comparativamente a outra máquina comercialmente disponível, uma máquina de ensaio de impacto especificamente destinada a materiais biológicos, com possibilidade de variação dos vãos entre os apoios dos corpos de prova, o que flexibiliza o ensaio de acordo com as características de cada material.

Palavras-chave: máquina de impacto, ossos longos, ensaio de impacto, ensaio dinâmico. 


\begin{abstract}
SANTOS, R. M. (1999). PROJECT AND ADAPTATION OF AN IMPACT TESTING MACHINE FOR LONG BONES OF SMALL AND MEDIUM-SIZED ANIMALS. Ribeirão Preto, 1999. 57p. Dissertação (Mestrado) - Curso de Pós-Graduação Interunidades Bioengenharia - USP (Escola de Engenharia de São Carlos / Faculdade de Medicina de Ribeirão Preto / Instituto de Química de São Carlos).
\end{abstract}

Fractures of long bones are generally caused by dynamic impact loads (shock). Studying clearing the behaviour of bones submitted to controlled impact tests may contribute to deepen the general knowledge on the phenomena involving the event of fractures. The impact tests are usually carried out with a specially designed machine, provided with a pendulum hammer which strikes on specimens of the tested material. However, the commercially available impact testing machines are designed for isotropic materials, of definite shape and dimensions according to standards specific for each material, which are not adapted for biologic materials. The biologic materials are in general anisotropic by nature, what prevents the construction of test pieces with rigorously standardised shape and dimensions, as it happens with non-biological materials. Therefore, especially designed impact testing machine should be developed for this purpose. Its a main characteristic would be that the test pieces supports can be changed and moved, to adapt to their shapes and dimensions.

The design, development and test of as impact testing machine specifically designed for bone, comparing it to another commercially available machine, was the aim of this work machine developed enables the variation of the distance between the test piece supports, which allows to carry out tests according to the physical characteristics of any test piece.

Keywords: impact machine, long bones, impact test, dynamic assay. 


\section{INTRODUÇÃo}

O comportamento de um material, pode ser avaliado através de suas propriedades mecânicas, por meio de ensaios com a aplicação de cargas estáticas.

O conhecimento de tais propriedades auxilia os profissionais dedicados a reabilitação óssea a entender o comportamento dos ossos no organismo de acordo com sua arquitetura e função e, também, se outros materiais podem ser utilizados para substituir os ossos ou parte deles, como no caso dos implantes.

A resistência mecânica dos materiais depende da forma como a carga é aplicada e da deformação resultante ocorrida. Muitos podem resistir a grandes carregamentos se as cargas forem aplicadas durante um longo período de tempo (ensaios estáticos). Se uma carga é aplicada repentinamente (ensaios dinâmicos), o material pode falhar e parecer ter menor resistência (HORATH, 1995). Dos ensaios dinâmicos que podem ser realizados, o de impacto é o que mais se aproxima da simulação das fraturas de ossos ocasionadas por acidentes, sendo um dos primeiros ensaios empregados no estudo de fratura frágil de materiais em geral.

Devido ao fato das propriedades dos materiais dependerem da taxa de deformação, ensaios têm sido propostos e normatizados para determinar a energia requerida para romper uma amostra de um material, quando submetida a carregamento repentino. Estes ensaios são chamados de "ensaios de impacto". O resultado geral deste ensaio é a determinação da energia absorvida por um corpo de prova durante a ocorrência de sua fratura.

As cargas de impacto são aplicadas em estruturas e máquinas de várias maneiras. Estas cargas incluem cargas móveis de aplicação rápida, como as produzidas por uma 
locomotiva passando sobre uma ponte; cargas de aplicação repentina, como ocorre durante a explosão da mistura combustível dentro do cilindro de um motor a combustão interna; cargas de inércia, como as introduzidas pelas altas acelerações e transferência de energia cinética que acompanham choques mecânicos; cargas de impacto direto, como as cargas produzidas pela queda de um martelo de impacto.

O ensaio de impacto foi um dos primeiros e até hoje um dos mais empregados para o estudo das fraturas nos materiais. Com o avanço nas áreas tecnológicas apareceram ensaios mais sofisticados e elaborados para obtenção das propriedades mecânicas dos materiais, porém nenhum superou a simplicidade e velocidade de execução do ensaio de impacto.

\subsection{PROPRIEDADE MECÂNICA DOS OSSOS}

As primeiras citações relativas às propriedades mecânicas dos ossos são atribuídas a Galileu (1638), que se referiu a importância mecânica da forma do osso. Galileu fez importantes descobertas aplicando a Mecânica de corpos rígidos, ainda hoje utilizada na maioria dos métodos de análise.

A frequiência das ocorrências de fraturas e deformidades nos ossos longos fornece bons motivos para o estudo de leis que regem a arquitetura interna destes ossos, de grande valor prático e teórico.

Os ossos longos têm sido mais cuidadosa e extensivamente estudados que os outros ossos. Isto é explicado pela complexidade da sua estrutura interna, do seu comprimento, do seu formato incomum e da grande importância destes ossos na sustentação e movimentação dos organismos a que pertencem.

Se a estrutura mecânica dos ossos longos é relacionada, em termos matemáticos, com uma estrutura de formato e propriedades físicas semelhantes, estrutura esta projetada para resistir a ação de cargas iguais em módulo, direção e sentido de aplicação, é razoável supor que a estrutura dos ossos longos é baseada em leis matemáticas exatas e, adicionalmente, que esta é a lei geral da arquitetura óssea: o formato do osso é adaptado as 
suas funções. Assim sendo, variações nas cargas estáticas exercidas sobre os ossos, correspondem a alterações nas estruturas interna e externa dos mesmos, provocando deformações. Se estas variações nas condições estáticas fossem sufícientemente grandes, produziriam alterações de contorno marcantes no osso, ocasionando também um deslocamento da condição normal. Tanto alterações de contorno como deslocamento devem ser consideradas como adaptações físiológicas às condições mecânicas da estrutura.

A dificuldade de se examinar a estrutura óssea utilizando as leis da Mecânica é que estas leis são descritas para corpos rígidos que possuem uniformidade estrutural; como o osso é anisotrópico, ocorre uma variação das propriedades ósseas para diferentes amostras com as mesmas propriedades geométricas, ou seja, para corpos de prova de mesmas dimensões, devido à variação microestrutural, introduzindo desta forma mais uma variável nas propriedades mecânicas que é a morfologia do osso.

Há várias razões para se estudar as propriedades mecânicas dos ossos. Primeiro, o conhecimento das propriedades mecânicas torna possível a avaliação do funcionamento do osso in vivo; isto é importante para os procedimentos cirúrgicos ortopédicos onde a função do osso tem que ser substituída por um implante temporário, como ossos estabilizados por pinos intramedulares ou placas ou onde parte de uma estrutura óssea é substituída por um implante permanente. Segundo, o entendimento das propriedades mecânicas e suas relações com as estruturas ósseas aumenta o conhecimento fundamental do osso como um material e como parte de uma estrutura de cargas distribuídas.

\subsection{OSSO COMO UM MATERIAL}

A resistência mecânica do osso é aproximadamente $1 / 10$ da resistência à tração do aço. A estrutura de apatita do osso é a base para uma excelente resistência à compressão. Os elementos responsáveis pela resistência à tração, as fibras de colágeno, são mais fracos que os cristais de apatita. A resistência à tração da tíbia é $20 \%$ menor que a sua resistência à compressão (KNETS, 1993). A resistência mecânica do osso esponjoso é muito variável e 
normalmente menor que $1 / 10$ da resistência mecânica do osso cortical como demonstrado por YAMADA e EVANS (1970).

Uma propriedade dominante do osso é a sua fragilidade, pois ele comporta-se mais como o vidro do que como a borracha. Quando o osso sofre um carregamento de tração, ele quebra tendo atingido somente 2 \% de deformação (MÜLLER et al., 1993).

O osso serve de estrutura de apoio para tecidos moles possibilitando a locomoção. Para funcionar como um esqueleto o osso deve ser rígido, pois durante as atividades normais e esportivas, o osso deve resistir a uma grande variedade de esforços.

A fratura do osso é o resultado de uma sobrecarga mecânica que interrompe em fração de segundos a integridade estrutural e, com isso, sua rigidez. 0 tipo de fratura depende do tipo de carga aplicada e da quantidade de energia transferida. Torque resulta em

uma fratura em espiral, flexão em fraturas curtas e obliquas, enquanto compressão axial resulta em fraturas de impactação (fraturas sem contato entre os fragmentos principais após restauração do comprimento original). 0 grau de fragmentação depende da quantidade de energia absorvida no processo de fratura. Neste caso cabe ao ensaio de impacto esclarecer a relação da energia transferida no impacto e o grau de fragmentação do osso. Portanto, os ensaios mecânicos são importantes para o esclarecimento da relação entre as fraturas ósseas com as cargas aplicadas e a velocidade de sua aplicação (MÜLLER et al., 1993).

\subsection{ENSAIOS ESTÁTICOS}

Os ensaios estáticos utilizam corpos de prova ou estruturas inteiras, de materiais biológicos e não biológicos, aplicando incremento de força a pequenas velocidades, com o objetivo de obter as propriedades mecânicas desejadas utilizando as equações da Mecânica. Estas propriedades ajudam a entender o comportamento de um material e calcular sua resistência mecânica a um determinado carregamento estático. 


\subsection{ENSAIOS DINÂMICOS}

Nos ensaios dinâmicos, as cargas aplicadas nos materiais não são mais consideradas estáticas devido ao aumento na velocidade de aplicação do carregamento. Existem três tipos de propriedades, correspondendo a três tipos de condições de carregamento dinâmico: (1) propriedades de fadiga para carregamentos repetitivos ou flutuantes, (2) propriedades de amortecimento para condições de cargas ressonantes e (3) propriedades de impacto para cargas aplicadas repentinamente (MARIN, 1962).

\subsection{ENSAIO DE IMPACTO}

As cargas de impacto podem ser classificadas em termos de aplicação repentina de força, rápida mudança na velocidade e carregamentos irregulares de choque. Normalmente, carregamentos de choque envolvem poucos ciclos de carga. Contudo, em alguns casos, como nos acopladores ferroviários, a estrutura deve suportar milhares de cargas de impacto. Este tipo de carregamento é chamado de carregamento de fadiga por impacto (MARIN, 1962).

Quando forças são aplicadas repentinamente, por curtíssimos períodos de tempo, um efeito causado por estas é a produção de ondas de tensão. A influência destas cargas é duplicada, pois modificam as tensões e deformações produzidas, como também as propriedades de resistência do material.

O impacto envolve não somente uma colisão de corpos, mas também uma rápida aplicação de força ou movimento a uma estrutura, cujos danos provocados são dependentes das características desta. Na maioria dos casos, se o tempo de aplicação da carga é menor que metade do menor período natural de vibração, a carga é defínitivamente considerada como carga de impacto. Se o intervalo de tempo é maior que três vezes o período natural, a carga é geralmente considerada estática. $\mathrm{O}$ tempo de carregamento referido acima é o tempo requerido para aumentar a carga de zero até o valor máximo (MARIN, 1962).

Existem vários modelos teóricos que tentam descrever o comportamento do material quando submetido a uma carga de impacto, porém métodos experimentais ainda são 
necessários para se obter estas propriedades com mais exatidão. $\mathrm{O}$ método experimental mais fácil de ser empregado é a produção de ondas de tensão em um sólido pela colisão de uma massa, onde geralmente é utilizado um martelo de impacto.

\subsubsection{Ensaio de Impacto em Corpos de Prova Entalhados}

Através do ensaio de impacto pode-se medir a tendência do comportamento de um material. Neste ensaio há a necessidade de se definir previamente as características geométricas dos materiais ensaiados, devido ao fato de se tratar de um ensaio comparativo, sendo que somente corpos de prova com as mesmas dimensões e configuração de carregamento podem ser comparados. Para facilitar a comparação e concentrar o local da fratura é feito um entalhe, quando o material ensaiado é um metal. Sem o entalhe as tensões se distribuiriam uniformemente ao longo do corpo de prova; a existência de um entalhe provoca um estado triaxial de tensões (tensão radial, longitudinal e transversal ao entalhe). A FIGURA 1.1 mostra diferentes corpos de prova com entalhe. Pode-se também dividir a energia absorvida após o impacto pela área útil da secção transversal do corpo de prova, obtendo-se a energia por unidade de área.

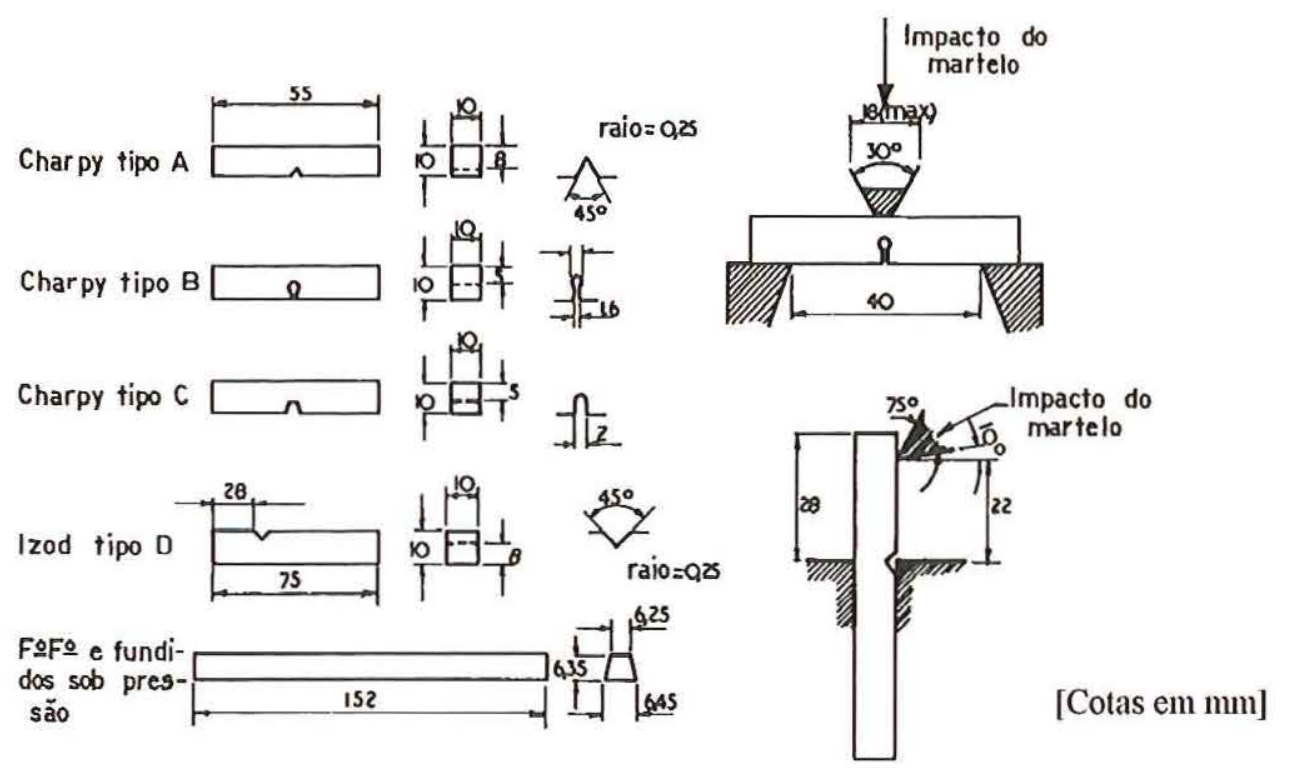

FIGURA 1.1 - Corpos de prova recomendados pelas Normas DIN, ASTM e ABNT para ensaio de impacto e local de impacto do martelo. 
O entalhe não somente concentra a tensão, como induz a produção de uma fratura frágil no local de ruptura; mesmo assim, não é possível medir com exatidão os componentes de tensão existentes, pois variam de acordo com a estrutura interna do material ensaiado.

\subsubsection{Procedimentos Experimentais}

Quando a velocidade de um corpo em movimento é modificada, uma transferência de energia deve ocorrer; o trabalho é realizado nas partes que recebem o impacto. A mecânica do impacto envolve não somente a questão da tensão induzida, mas também considerações de transferência, absorção e dissipação de energia. A absorção de energia de impacto pode ocorrer de várias maneiras: através da deformação elástica dos membros ou partes do sistema, das deformações plásticas nas partes, dos efeitos de histerese nas partes; da ação friccional entre as partes e dos efeitos da inércia nas partes móveis.

No projeto de estruturas e máquinas, um esforço deve ser feito para prover absorção do quanto for possível de energia através da ação elástica e secundariamente alguma forma de amortecimento para dissipá-la. Durante anos, o desenvolvimento de um ensaio de impacto para avaliar as relações de tensão e deformação de um material era feito em peças não entalhadas, dificultando a análise da região fraturada; posteriormente, com o advento da padronização dos ensaios de impacto com cargas de flexão, foram adotados os corpos de prova tipo Charpy (FIGURA 1.2.a) e Izod (FIGURA 1.2.b), que possuem um entalhe como forma de precipitar a fratura naquela região.

O corpo de prova tipo Charpy é suportado pelas extremidades e colidido no centro; é uma barra de secção transversal quadrada, entalhado no centro de seu comprimento. Uma das razões para a introdução de um entalhe como forma de concentrar a tensão é que materiais dúteis podem ser fraturados. A sensibilidade ao entalhe pode ser avaliada pela comparação da energia absorvida pelo corpo de prova entalhado versus corpo de prova sem entalhe. $\mathrm{O}$ corpo de prova do tipo Izod é uma viga em balanço com um entalhe no lado tracionado para assegurar que haja fratura quando a carga for aplicada neste lado. 


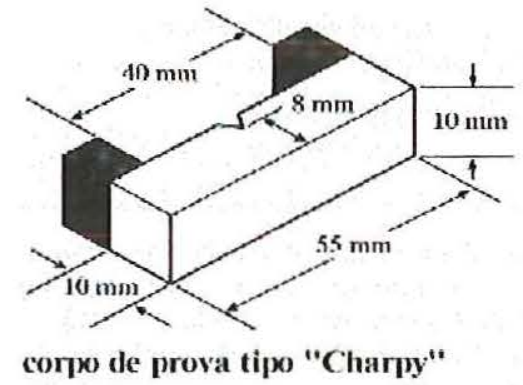

(a)

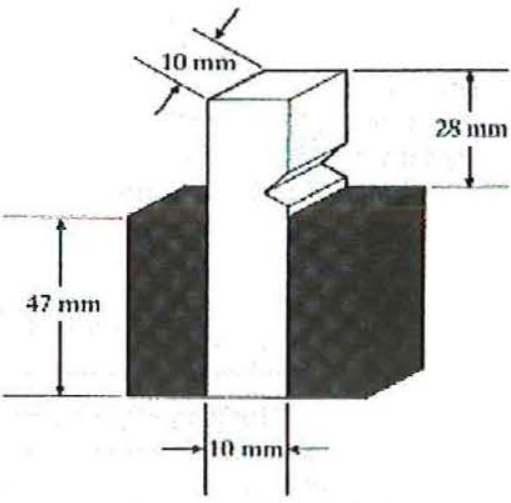

corpo de prova tipo "Izod"

(b)

FIGURA 1.2 - Corpos de prova tipo Charpy e Izod. Fonte: HORATH (1995).

No ensaio tipo Charpy é utilizada uma máquina tipo pêndulo (FIGURA 1.3). O disco pendular $P$, de peso $W$, é liberado e cai de uma altura $h$, empurrando o indicador $N$ ao redor de uma escala $E$ até o pêndulo atingir a altura $h$ ". Ao ser liberado o pêndulo percorre uma trajetória de um arco de círculo, colide com o corpo de prova e provoca a fratura. Após a fratura do corpo de prova, o pêndulo alcança um altura máxima $h$ ". $\mathrm{O}$ indicador $N$ não retorna a posição inicial como o pêndulo, permanecendo no ponto mais alto da altura de queda $h$ ". A energia para fraturar o corpo de prova, também chamada de resistência ao impacto, normalmente expressa em Joules, é aproximadamente igual a:

$$
U_{T}=W_{h}-W_{h "}
$$

Onde:

$h$ - altura de queda vertical do centro de gravidade do pêndulo de peso $W$.

$h$ " - altura de ascensão vertical do centro de gravidade do pêndulo de peso $W$. 


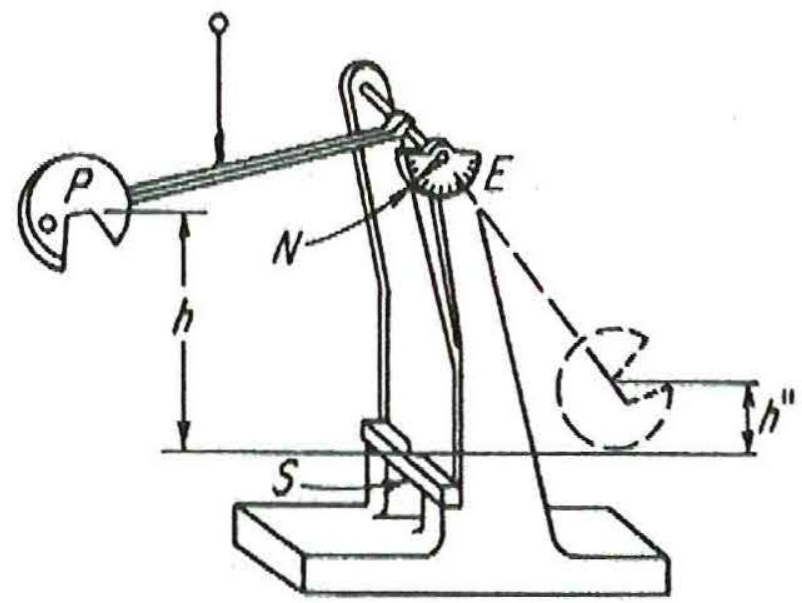

FIGURA 1.3 - Máquina de impacto tipo Charpy.

FONTE: MARIN (1962).

A energia absorvida pode ser determinada, em termos angulares, através da liberação do pêndulo de um ângulo $\alpha$ conhecido (FIGURA 1.4). Teoricamente se o pêndulo não encontrar qualquer resistência, ele subirá até um ângulo $\alpha$ no lado oposto. Esta teoria despreza o efeito do atrito, que deve ser levado em conta no cálculo da energia requerida para fraturar o corpo de prova. Quando o martelo encontra o corpo de prova durante a queda, transfere energia para este, rompendo-o e alcançando o lado oposto a um ângulo $\beta$. A energia requerida para fraturar o corpo de prova pode ser calculada pela equação que segue:

$$
E_{r}=m g L(\cos \beta-\cos \alpha)
$$

Onde:

$E_{r}$ - energia requerida para quebrar o corpo de prova, em $J$;

$m$ - massa do pêndulo, em $\mathrm{kg}$;

$g$ - aceleração da gravidade, em $\mathrm{m} / \mathrm{s}^{2}$;

$L$ - comprimento do pêndulo, em $m$;

$\alpha$ - ângulo inicial ou ângulo de queda, em graus;

$\beta$ - ângulo final ou ângulo de subida, em graus. 


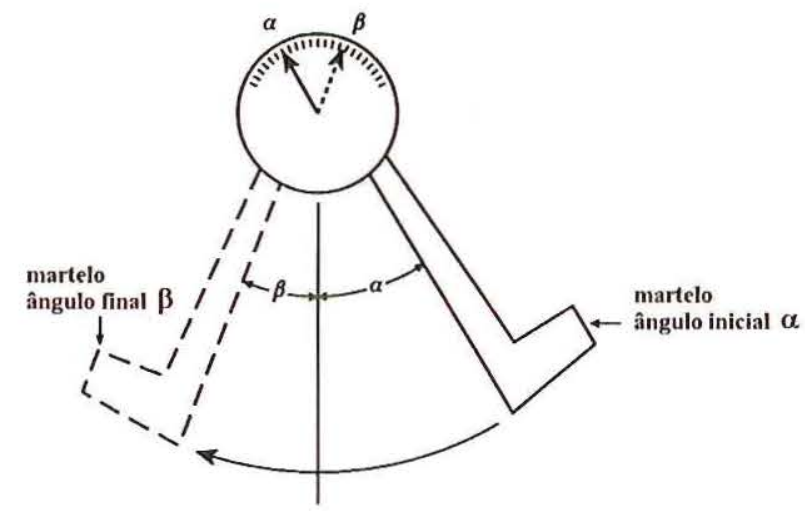

FIGURA 1.4 - Condições do ensaio de impacto.

Fonte: HORATH (1995).

No caso dos corpos de prova não entalhados, a tensão é essencialmente de tração e uniformemente distribuída. Nos ensaios com corpos de prova entalhados, o estado de tensão em torno do entalhe é triaxial e não uniformemente distribuído ao longo do corpo de prova, suficiente para provocar uma ruptura com características de material frágil, apresentando pouca deformação plástica (HORATH, 1995). Os componentes das tensões existentes podem variar conforme o metal usado no ensaio ou conforme a estrutura interna que este apresenta. Deste modo, o ensaio de impacto em corpos de prova entalhados tem limitada significação e interpretação, sendo úteis apenas para fim de comparação dos materiais ensaiados nas mesmas condições pois provêm valores proporcionais de resistências devido ao entalhe, não fornecendo um valor acurado de resistência ao impacto (SOUZA, 1974).

A resistência ao impacto, obtida pelo ensaio de impacto em corpos de prova entalhados, é influenciada por uma série de fatores: a máquina de teste irá influenciar os resultados visto que a energia absorvida pode variar de máquina para máquina; a velocidade de impacto irá modificar naturalmente os resultados do ensaio; a forma e o tamanho do entalhe irá influenciar a resistência ao impacto, pois uma diminuição desta resistência ocorre com o aumento do tamanho do entalhe (MARIN, 1962). 
Segundo a normatização existente, os itens a serem avaliados no ensaio de impacto são: fundação para fixação da máquina, apoios e suportes do corpo de prova, forma e entalhe do corpo de prova, massa pendular e velocidade de impacto da massa pendular.

Os principais requisitos de uma máquina de ensaio de impacto devem ser:

1) Uma massa pendular que deve fornecer energia cinética suficiente para causar ruptura do corpo de prova colocado no caminho;

2) Um apoio lateral e um suporte no qual o corpo de prova é colocado;

3) Recurso para medir a energia residual da massa móvel após a ruptura do corpo de prova.

A energia cinética é determinada pela massa do pêndulo e altura de queda a partir do centro de massa do pêndulo. $O$ pêndulo deve ser fixado ao eixo de rotação de forma tal que reduza o desvio lateral e a fricção na oscilação quando da queda em direção ao corpo de prova. $\mathrm{O}$ mecanismo de queda deve ser construído para reduzir qualquer desaceleração ou aceleração do movimento e também efeitos vibratórios.

O suporte deve ser pesado o sufíciente em relação à energia de golpe, para que a energia de impacto não seja perdida devido a qualquer tipo de deformação ou de vibração das partes da máquina (HORATH, 1995).

\subsubsection{Ensaio de Impacto em Materiais Biológicos}

A maioria das atividades na vida diária, seja andar, correr ou mesmo levantar-se de uma cadeira, envolve padrões de carregamento de natureza impulsiva, onde o pico de carga durante a atividade pode ser muito alto em um curto período. Se o pico for muito alto, o osso pode fraturar; por esta razão, a maioria das fraturas não são resultado de cargas aplicadas lentamente e sim de cargas dinâmicas. Fratura é o meio mais efetivo de absorver energia, porém, se o pico de força for de curta duração, o sistema esquelético é capaz de atenuar a maior parte dele. Todo esta interação entre sistema esquelético e cargas suportadas é de difícil avaliação devido à viscoelasticidade do osso, tornando suas propriedades mecânicas 
como resistência ao choque e rigidez, dependentes da taxa de aplicação da carga e velocidade de impacto (BIRD e BECKER, 1966).

Tem sido demonstrado que a atenuação do pico de força dinâmica não é função do fluido sinovial e da cartilagem articular, e sim do osso e tecidos moles (RADIN e PAUL, 1970). Embora os ossos e tecidos moles não sejam tão elásticos quanto a cartilagem articular e o fluido sinovial, eles são compactos e existem em grandes quantidades, permitindo que haja deformação suficiente para a absorção da energia transferida pelo impacto, enquanto que fluido e cartilagem ocupam camadas relativamente finas e não possuem esta propriedade de absorção do impacto. Mesmo não sendo responsável pela absorção do impacto, a cartilagem articular sofre seus efeitos em forma de microfraturas durante a movimentação, provocadas pelo contato com o osso subcondral. A variação no grau de reparação, ou seja, danos maiores que a capacidade de reparação é que são responsáveis pelo início de doenças articulares.

As fraturas características de amostras de osso cortical sem entalhe (sem fendas ou fraturas produzidas artificialmente na superfície óssea) foi estudada por EVANS (1973), mas pouca atenção foi dada para o estudo de corpos de prova de osso entalhado. Foi demonstrado por BONFIELD e LI (1966) que a presença de fendas na superfície reduz signifícativamente a energia absorvida durante a fratura de secções de fêmures e tíbias bovinas sob impacto, tanto quando o ensaio é feito na orientação longitudinal quanto no sentido transversal. Estes resultados foram confirmados por POPE e OUTWATER (1972), medindo a energia para fraturar amostras de vários tipos de ossos entalhados submetidos ao impacto.

HERT et al. (1965) realizaram ensaios de impacto em corpos da prova de ossos bovinos com comprimento de $40 \mathrm{~mm}$ e diâmetro de $5 \mathrm{~mm}$. Utilizaram uma máquina de impacto com pêndulo tipo Charpy, obtendo a energia absorvida pelas amostras após o choque com o martelo de impacto. Verificaram uma grande dispersão nos valores de energia obtidos que variaram de 0,7 a 2,0 kgf.cm. Essa dispersão foi atribuída principalmente à baixa sensibilidade da máquina de ensaio, diferenças nas orientações de retirada dos corpos de 
prova, diferenças nos graus de mineralização do osso que, juntamente com os outros componentes microestruturais, influenciam diretamente nas propriedades mecânicas. Na análise microestrutural com a energia de impacto, os pesquisadores perceberam que não houve diferença entre a energia absorvida pelo osso primário e secundário.

BIRD e BECKER (1965) utilizaram corpos de prova de ossos bovinos para realizar o ensaio de impacto em diferentes velocidades. Os corpos de prova foram ensaiados frescos utilizando uma velocidade de impacto que variou de 89 a $384 \mathrm{ft} / \mathrm{s}(27,1$ a $117 \mathrm{~m} / \mathrm{s})$. Houve grande variação nos tipos de fraturas provocadas pelo impacto. Um dos resultados mais interessantes obtidos foi a maior resistência de ossos inteiros comparados com corpos de prova. As fraturas observadas no ensaio de impacto em corpos de prova de ossos a $200 \mathrm{ft} / \mathrm{s}$ $(61 \mathrm{~m} / \mathrm{s})$ correspondem àquelas observadas em ossos inteiros a $800 \mathrm{ft} / \mathrm{s}(244 \mathrm{~m} / \mathrm{s})$.

CURREY (1979) realizou ensaios de impacto em corpos de prova retirados de fêmures humanos, tentando verificar a relação existente entre energia absorvida no impacto, expressa em J.m $\mathrm{m}^{-2}$, idade, quantidade de cálcio, densidade e porosidade do osso. Com relação à idade, notou que a energia absorvida decresce com o aumento da idade, sendo que os ossos mais jovens absorveram em média $2,8 \times 10^{4} \mathrm{~J}_{\mathrm{m}} \mathrm{m}^{-2}$ e os mais velhos, correspondendo a idades que chegam a 90 anos, absorveram em média $1,0 \times 10^{4} \mathrm{~J}_{\mathrm{m}} \mathrm{m}^{-2}$. Esta redução de aproximadamente 3 vezes da energia absorvida com o aumento da idade é importante, não só do ponto de vista mecânico, como do ponto de vista clínico, visto que estes valores são maiores do que as variações correspondentes às propriedades obtidas nos ensaios estáticos de resistência (CURREY e BUTLER, 1975; BURSTEIN et al., 1976). A energia absorvida pelos fềmures apresentou uma correlação negativa com a densidade e com a quantidade de cálcio, ou seja, quanto maior a densidade e/ou a quantidade de cálcio do osso, menor a energia que ela absorverá. Esta relação mostrou-se significativa na regressão, utilizando escala logarítmica para a energia absorvida. A porosidade mostrou não afetar a energia absorvida, ou seja, não houve variação significativa da energia absorvida com o aumento da 
porosidade, porém, principalmente em ossos de pessoas idosas, a alta porosidade tem um efeito danoso reduzindo o volume de material ósseo.

O fềmur humano também foi estudado por MOYLE e BOWDEN (1984) utilizando a técnica desenvolvida por TATTERSAL e TAPPIN (1966), que obtém a energia absorvida até o início da propagação da fratura, e que é chamada de "trabalho de fratura". Para os ensaios foram utilizados corpos de prova de várias regiões dos fềmures, com $45 \mathrm{~mm}$ de comprimento, $7 \mathrm{~mm}$ de largura e $6 \mathrm{~mm}$ de espessura, sendo que, no centro do corpo de prova, foi entalhado um triângulo como forma de precipitar o local de propagação da trinca. A média do "trabalho de fratura" foi $(7,8 \pm 2,1) \times 10^{3} \mathrm{~J}_{\mathrm{m}} \mathrm{m}^{-2}$. A média deste trabalho, para o lado medial, foi $(8,5 \pm 2,0) \times 10^{3} \mathrm{~J}_{\mathrm{m}} \mathrm{m}^{-2}$ e para o lado lateral foi $(7,2 \pm 2,1) \times 10^{3} \mathrm{~J} . \mathrm{m}^{-2}$; nenhuma diferença significativa foi encontrada para estes dois grupos.

MOYLE et al. (1978) estudaram o "trabalho de fratura" de corpos de prova de fềmures caninos, retirados das regiões lateral e medial, utilizando a técnica de TATTERSAL e TAPPIN (1966) para obtenção da energia absorvida até a fratura. Calcularam também o tamanho e a densidade dos osteons presentes nas regiões fraturadas. Para o "trabalho de fratura", obtiveram $(6,96 \pm 1,35) \times 10^{3} \mathrm{~J}_{\mathrm{m}} \mathrm{m}^{-2}$ para os corpos de prova retirados da porção medial e $(11,8 \pm 3,0) \times 10^{3} \mathrm{~J} . \mathrm{m}^{-2}$ para os corpos de prova da porção lateral, havendo diferença significativa do "trabalho de fratura" para as duas regiões. Para o tamanho e densidade dos osteons das secções transversais dos corpos de prova, não houve diferença entre as regiões medial e lateral, mostrando que não há relação entre o "trabalho de fratura" e o tamanho e densidade de osteons das secções transversais.

VIANNO e STALNAKER (1980) realizaram ensaios de impacto com aplicação de carga na direção axial de fềmures humanos dissecados, com a articulação do joelho e os ligamentos intactos. $\mathrm{O}$ objetivo foi simular uma colisão na articulação, semelhante àquela que ocorre em um acidente automobilístico, para verificar qual a carga de impacto axial suportada pelo fêmur. A média dos picos de carga foi $(10,6 \pm 2,7) \mathrm{kN}$ após $(1,3 \pm 0,1) \mathrm{cm}$ de 
deformação compressiva para uma carga de impacto de $10,1 \mathrm{~kg}$ aplicadas a uma velocidade de $(13,2 \pm 1,4) \mathrm{m} / \mathrm{s}$. As deformações ortogonais ao plano de carga ocorridas nos fêmures medidas através de strain gages aumentavam mesmo de depois do pico de aplicação de carga, até que houvesse início de fratura para dissipação de energia e diminuição das deformações ortogonais (sentido ântero-posterior e latero-medial).

A falange média bovina foi utilizada por RADIN e PAUL (1971) para estudar o efeito da cartilagem e do osso na absorção de carga após o impacto axial. Para isto, amostras da parte proximal da falange, foram colocadas em um cilindro onde foi aplicado um impacto axial com um pistão de $2,27 \mathrm{lb}(\cong 1 \mathrm{~kg})$ posicionado a uma altura de $1 / 16$ " e $1 / 8$ "do cilindro. Para verificar a influência do osso e da cartilagem na absorção da carga, o primeiro ensaio foi feito com a falange intacta, o segundo sem a cartilagem e o terceiro sem a cartilagem e com a retirada de $50 \%$ do osso. A retirada de 0,025 polegadas $(0,635 \mathrm{~mm})$ de cartilagem provocou uma redução no pico de força de $8 \%$, enquanto que com a retirada de $50 \%$ de osso correspondendo a 1,10 polegadas $(\cong 28 \mathrm{~mm}$ ) de osso produziu um aumento no pico de força de $40 \%$. Comparando as quantidades de pico de força absorvida pelos dois tipos de tecido, a cartilagem foi 10 vezes mais efetiva que o osso subcondral na redução do pico de força. Assim, foi concluído que a cartilagem, apesar de ter uma pequena espessura quando comparada com o osso, tem uma grande eficiência na absorção do impacto.

McELHANEY (1966) ensaiou corpos de provas de fềmures humanos a compressão utilizando taxas de deformação baixas que foram de 0,001 a $1 \mathrm{~s}^{-1}$ e altas que foram de 1 a $1500 \mathrm{~s}^{-1}$. Á medida que foi sendo utilizada uma velocidade maior para o ensaio, a resistência máxima à compressão ia aumentando, tendo uma correlação positiva com a taxa de deformação, colocando esta em escala logarítmica. Uma velocidade crítica pode ser considerada quando as propriedades do material exibem uma grande variação na tensão máxima para uma pequena variação na taxa de deformação. Nestes ensaios foi verificada uma grande variação da energia absorvida para as taxas de deformação entre $0,1 \mathrm{e}^{1} \mathrm{~s}^{-1}$. 
Acima de $1 \mathrm{~s}^{-1}$, a capacidade do osso de absorver energia não apresentou grande variação. 0 autor verificou que baixas taxas de deformação produziram pequena propagação de trinca, ocasionando fratura semelhante à falha de um concreto sob compressão (fratura linear). Com o aumento da velocidade houve uma maior propagação das trincas, fazendo com que o osso se quebrasse em vários pedaços (fratura cominutiva) após a falha. 


\section{OBJETIVO}

Com o objetivo de quantificar a energia absorvida por materiais biológicos (ossos longos de animais de pequeno e médio porte), devido a um carregamento de impacto, foi desenvolvido o projeto e confeccionada uma Máquina de Ensaio de Impacto (MEI - 50), que permita o ajuste da distância entre os apoios às dimensões das peças a serem ensaiadas. 


\section{MATERIAL E MÉTODOS}

\subsection{DEFINIÇÕES}

As definições utilizadas para as designações das partes da máquina de impacto seguem a Norma Européia EN 10.045 - Partes 1 e 2, e são descritas a seguir:

- Apoios verticais: partes da máquina formando um plano vertical que limitam o avanço horizontal da peça ensaiada durante o impacto. O plano dos apoios verticais é perpendicular ao plano dos apoios horizontais.

- Suportes: partes da máquina formando um plano horizontal no qual a peça é apoiada antes de ser quebrada pelo martelo. O plano dos suportes é perpendicular ao plano dos apoios verticais.

- Percussor: parte do martelo que entra em contato com a peça ensaiada.

- Centro do percussor: ponto no lado de impacto do pêndulo, que quando o pêndulo é liberado, entra em contato com o plano horizontal do centro da peça ensaiada.

- Geometria da peça ensaiada:

- altura: distância entre a face entalhada e a face oposta;

- largura: dimensão perpendicular a altura e paralela ao entalhe;

- comprimento: maior dimensão da peça.

- Base da estrutura: parte da estrutura da máquina localizada abaixo do plano horizontal dos suportes. 


\subsection{MONTAGEM DA MÁQUINA DE IMPACTO}

Para a confecção da máquina foram utilizados os materiais listados na Tabela 3.1. As cantoneiras, chapas e barras são de aço 1020.

TABELA 3.1 - Relação dos materiais utilizados na construção da máquina de impacto.

\begin{tabular}{ccllc}
\hline N. $^{\circ}$ & Quant. & \multicolumn{1}{c}{ Material } & \multicolumn{1}{c}{ Utilização } & Especificação \\
\hline 1 & 01 & Chapa de aço de 1" & Base & $600 \times 350[\mathrm{~mm}]$ \\
2 & 02 & Cantoneira de aço & Apoios laterais & 4 "x4"x 1/2" \\
3 & $02 / 02$ & Chapa de aço de 3/4" & $\begin{array}{l}\text { Estruturas e suportes } \\
\text { laterais }\end{array}$ & $1000 \times 1000[\mathrm{~mm}]$ \\
4 & 04 & Chapa de aço de 1" & Martelo / Disco & $\varnothing 300[\mathrm{~mm}]$ \\
5 & 01 & Barra de aço circular $\varnothing 20 \mathrm{~mm}$ & Eixo & $210[\mathrm{~mm}]$ \\
6 & 32 & Parafuso allen & Fixação das cantoneiras & $1 / 2 " \times 11 / 4 "$ \\
7 & 12 & Parafuso allen & Fixação dos apoios & $1 / 4 " \times 1 / 2 "$ \\
8 & 02 & Rolamento de esferas & Eixo de rotação & $17 \times 35 \times 10$ \\
\hline
\end{tabular}

A chapa de aço N. ${ }^{\circ} 1$ (DESENHO 1)*, foi utilizada como base de sustentação das peças componentes da estrutura da máquina. Nela foram parafusadas as cantoneiras $\mathrm{N}^{\circ} 2$ (DESENHO 2), para dar sustentação ao conjunto. As estruturas laterais, obtidas da chapa $\mathrm{N}^{\circ}{ }^{\circ}$ 3, foram cortadas nas dimensões ${ }^{2}$ especificadas no (DESENHO 3), utilizando-se de um pantógrafo e parafusadas junto às cantoneiras na posição vertical; em sua parte superior foram feitos furos para o acoplamento dos rolamentos, $N .^{\circ} 8$, e do eixo de rotação, $\mathrm{N}^{\circ}{ }^{\circ}$. Desta mesma chapa foram confeccionados os suportes laterais (DESENHO 4), sendo soldados às cantoneiras e parafusados às estruturas laterais com a finalidade de evitar a movimentação horizontal das estruturas e aumentar a estabilidade do conjunto. As dimensões do disco do martelo, obtido da chapa N.$^{\circ} 4$ (DESENHO 5), foram determinadas através do cálculo da posição do centro de massa desta peça, para que este se localizasse o

\footnotetext{
${ }^{2}$ *Todos os desenhos detalhados estão em Anexos A.
} 
mais próximo possível da peça a ser ensaiado (o corpo de prova) e também das estruturas laterais. Na confecção do martelo foi utilizada a barra de aço circular N. ${ }^{\circ} 5$ (DESENHO 5) como haste desta estrutura, cortada no comprimento de $202 \mathrm{~mm}$, roscando o disco à barra em uma das extremidades e, na outra, um acoplamento, de dimensões especificadas no mesmo desenho, fazendo a ligação da haste do martelo com o eixo de rotação sustentado pelos rolamentos (FIGURA 3.1).

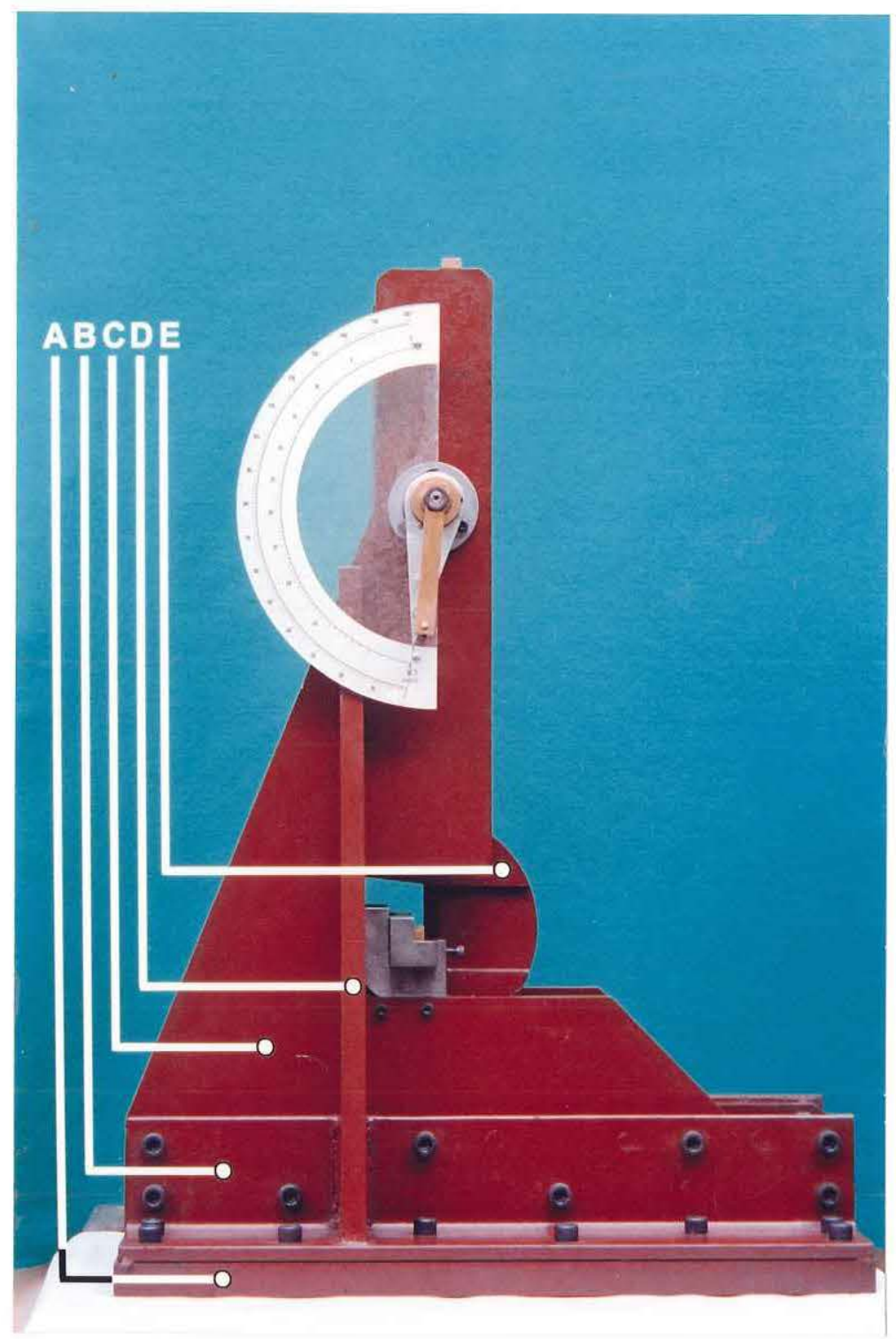

FIGURA 3.1 - Detalhamento construtivo da máquina de impacto para ensaios de ossos longos, com o martelo em posição de descanso. A - base de sustentação de toda a estrutura. B - cantoneiras. C - estruturas laterais. D-suportes laterais. E-disco do martelo. 
Os suportes e apoios dos corpos de prova foram fresados e plainados nas dimensões especificadas no DESENHO 6 e fixados à estrutura lateral utilizando os parafusos N. ${ }^{\circ}$ 7. Para o apoio do corpo de prova tomou-se o cuidado de verificar o ângulo entre a apoio vertical e o suporte (FIGURA 3.2) da peça que deve ser $90^{\circ} \pm 2^{\circ}$ (EN 10.045 - 1). De acordo com a mesma norma, o chanfro posterior dos apoios (DESENHO 6 - vistas frontal e superior) deveria obedecer a um ângulo de $11^{\circ} \pm 1^{\circ}$, porém, o ângulo de $45^{\circ}$ foi adotado na confecção. Este procedimento foi tomado com o intuito de evitar que o corpo de prova (osso) ficasse preso, entre o martelo e os apoios, durante a realização do ensaio, considerando que suas dimensões não são padronizadas como as especificadas para os ensaios de materiais não biológicos e, consequentemente, influenciar diretamente nos resultados dos ensaios.

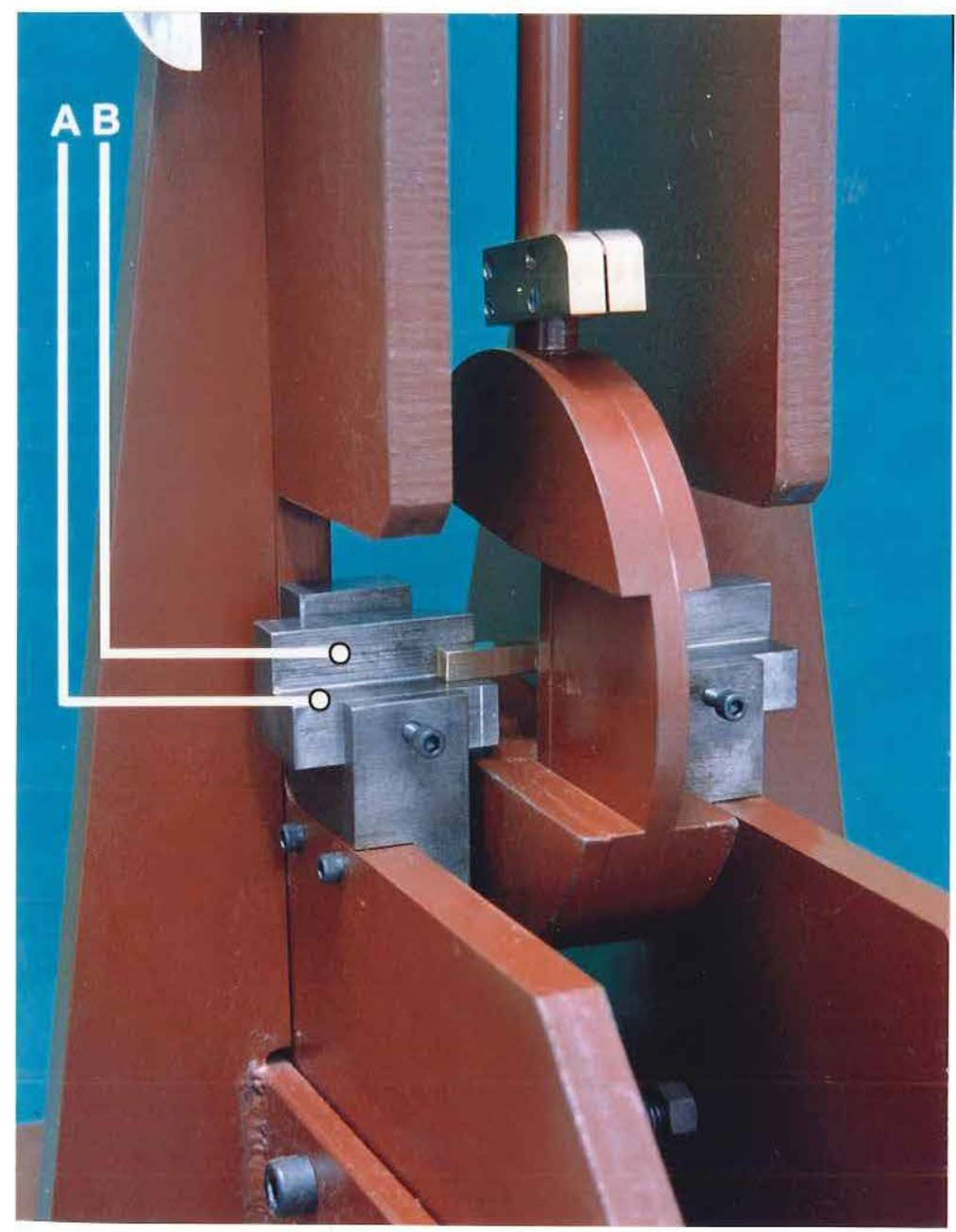

FIGURA 3.2 - Detalhamento dos apoios (A) e suportes (B) do corpo de prova. 


\subsubsection{Confecção da escala graduada}

A confecção da escala do goniômetro foi executada com base em ensaio preliminar realizado em uma máquina de ensaio de impacto HECKERT - PSd 50/15, operando por sistema digital, do Departamento de Engenharia de Materiais, Aeronáutica e Automobilística da Escola de Engenharia de São Carlos - USP, onde foram quantificadas as energias absorvidas por 11 pares de fềmures íntegros, sem tecidos moles, de coelhos da raça Nova Zelândia, com idade média de 8 semanas. A energia absorvida média obtida para os fềmures direitos, com sentido de aplicação de carga póstero-anterior foi de $(3,3 \pm 0,6) \mathrm{J}$; para os fềmures esquerdos, no sentido ântero-posterior, foi verificada $(2,9 \pm 0,8) \mathrm{J}$. Desta forma, estes resultados conduziram a determinação das dimensões do martelo ( Anexos A Desenho 5) para a obtenção de um fundo de escala de 50 Joules. Este valor de fundo de escala possibilita a execução de ensaios em ossos de vários animais de pequeno e médio porte.

\subsubsection{Verificação do alinhamento das peças da máquina}

Segundo a Norma Européia EN 10.045 - 2, algumas partes da máquina de impacto devem ser construídas com um índice fixado de tolerância para não afetar os valores das medidas nos ensaios. Por isso, na montagem da máquina, foram feitas as seguintes verificações de medida:

1) A máquina deve ser instalada em um plano de referência horizontal cujo desvio angular com relação ao plano vertical não deve ultrapassar $0,2 \%$.

2) $\mathrm{O}$ eixo de rotação do pêndulo deve ser paralelo ao plano de referência horizontal cujo desvio não deve ser maior que $0,2 \%$.

3) $O$ pêndulo deve oscilar em um plano perpendicular ao eixo de rotação cujo desvio não pode ser maior que $0,3 \%$. 
4) $O$ pêndulo deve ser posicionado de tal forma que o centro do percussor coincida com o plano médio entre os apoios verticais, sendo que qualquer desvio não pode ser maior que $\pm 0,5 \mathrm{~mm}$.

5) Os suportes devem ser montados paralelos a um mesmo plano. A variação das posições dos planos dos suportes não deve exceder $0,1 \mathrm{~mm}$.

6) O suportes devem ser montados de tal forma que quando a peça for posicionada, o seu eixo fique paralelo ao eixo de rotação com um desvio menor que $0,3 \%$.

7) Os apoios verticais devem ser posicionados no mesmo plano. A variação das posições dos planos dos apoios não deve exceder $0,1 \mathrm{~mm}$.

8) O ângulo formado entre o plano dos apoios verticais e o plano dos suportes deve ser $90^{\circ} \pm 0,1^{\circ}$

9) 0 ângulo entre a linha de contato do percussor e o eixo horizontal do martelo deve ser $90^{\circ} \pm 2^{\circ}$

10) Nenhuma parte do pêndulo que passe entre os apoios verticais deve ser maior que $18 \mathrm{~mm}$.

11) A resolução do indicador, $r$, é obtida dividindo a espessura do ponteiro pela mínima distância entre os centros de duas marcações adjacentes. Os valores recomendados para $r$ são: 1:4, 1:5 e 1:10. A distância entre duas marcações adjacentes deve ser no mínimo $2,5 \mathrm{~mm}$.

12) Uma divisão de escala não deve ser maior que $1 \%$ da energia potencial inicial e deve permitir a estimativa de um incremento de no mínimo $0,25 \%$ da energia potencial inicial.

\subsubsection{Determinação da aceleração da gravidade}

Para a determinação da aceleração da gravidade no local onde foram realizados os ensaios para aferição da máquina de impacto, foi utilizado um corpo cilíndrico maciço de latão com massa de $1,0 \mathrm{~kg}$, soldado a um fio inextensível de aço de comprimento $1,00 \mathrm{~m}$. 
O conjunto foi então fixado em um batente de uma porta do Laboratório de Bioengenharia da FMRP - USP. Abaixo, sem contato com o corpo, foi posicionada uma banqueta, com uma marcação de referência para orientação nas medidas dos períodos das oscilações.

Obedecendo um ângulo inferior a $5^{\circ} \mathrm{em}$ relação à direção vertical para a liberação do corpo, foram efetuadas 20 leituras de 16 oscilações cada. $\mathrm{O}$ valor médio obtido para o período relativo às oscilações foi de 2,01 segundos por oscilação, determinando assim o valor de $9,808 \mathrm{~m} / \mathrm{s}^{2}$ para a aceleração da gravidade, de acordo com a equação do pêndulo simples:

$$
g=\frac{4 \pi^{2} I}{T^{2}}
$$

Onde:

$g$ - aceleração da gravidade, $\mathrm{em} \mathrm{m} / \mathrm{s}^{2}$;

$l$ - comprimento do fio, em $\mathrm{m}$;

$T$ - período referente a uma oscilação, em $s$.

Este valor da aceleração da gravidade será utilizado, quando necessário, nos cálculos do projeto da máquina de ensaio de impacto pendular.

\subsubsection{Determinação da velocidade de impacto}

De acordo com a Norma Européia EN-10.045 - 2, a velocidade de impacto pode ser determinada pela equação:

$$
v=\sqrt{2 g L\left(1-\cos \theta_{0}\right)}
$$

Onde:

$v$ - velocidade, em $\mathrm{m} / \mathrm{s}$;

$g$ - aceleração da gravidade, em $\mathrm{m} / \mathrm{s}^{2}$;

$\theta_{0}$ - ângulo inicial de elevação, em graus, (FIGURA 3.3);

$L$ - distância entre o centro de impacto do martelo e o eixo de rotação, em $m$. 
Considerando a aceleração da gravidade de $9,808 \mathrm{~m} / \mathrm{s}^{2}$, o ângulo inicial de elevação do martelo de $160^{\circ}$ ( para obtenção da energia final de $50 \mathrm{~J}$ ) e a distância entre o centro de impacto do martelo e o eixo de rotação de $0,346 \mathrm{~m}$, a velocidade de impacto determinada foi de 3,628 m/s. Como observação importante, constata-se, de acordo com a equação anterior, que a velocidade de impacto independe da massa do pêndulo, TIPLER (1978).

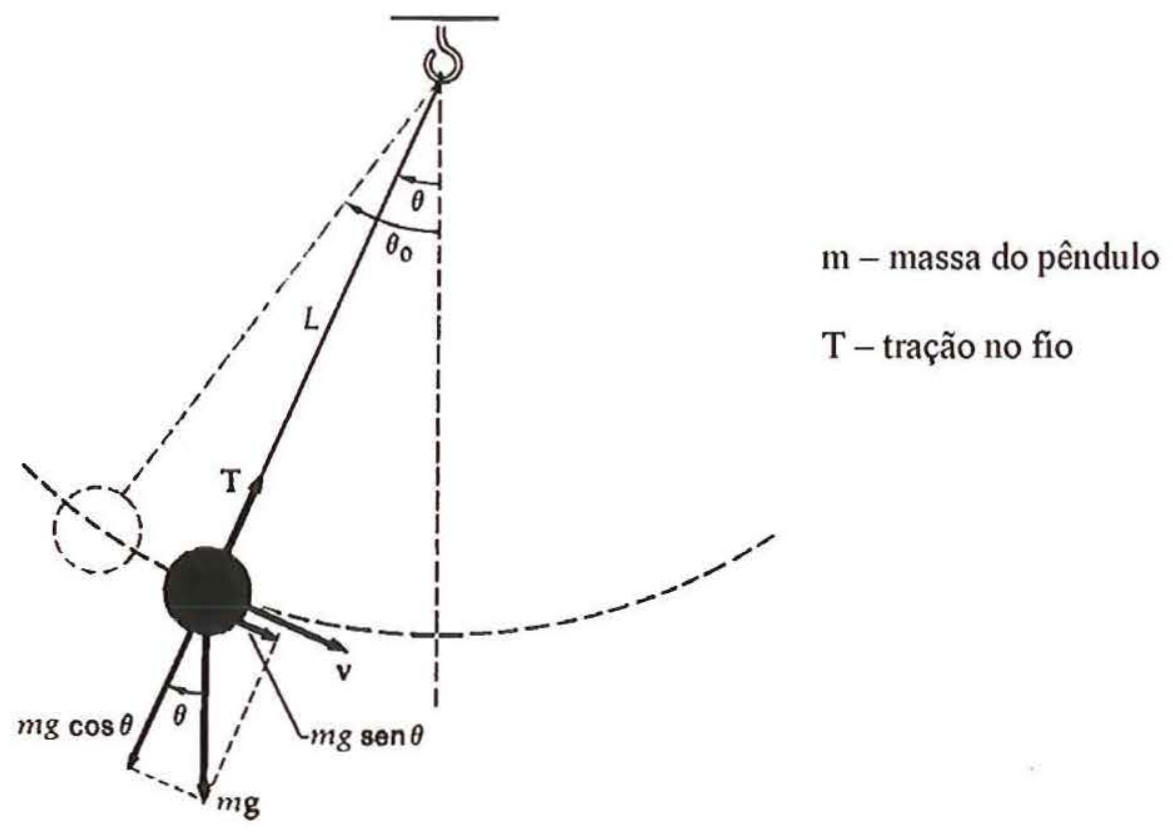

FIGURA 3.3 - Forças atuantes sobre um pêndulo simples. A velocidade no momento do impacto é determinada pela Lei da Conservação da Energia (4).

Fonte: TIPLER (1978).

\subsubsection{Energia absorvida}

Na determinação da energia absorvida pela quebra do corpo de prova, a peça ensaiada deve ser retirada de um lote cuja energia de impacto de referência seja conhecida.

Segundo a Norma Européia EN 10.045 - 2, deve-se considerar a energia total absorvida quando a peça é fraturada como sendo:

a) a energia requerida para quebrar a peça ensaiada;

b) a perda de energia interna da máquina de impacto durante a primeira metade do percurso de oscilação a partir da posição inicial. 
As perdas de energia são devido a:

a) resistência do ar, atrito do rolamento e atrito devido à resistência ao arrasto do ponteiro. Estas perdas podem ser determinadas pelo método direto;

b) vibração da fundação, da estrutura da máquina e do pêndulo, para as quais nenhum método de determinação foi desenvolvido.

Para a avaliação da energia absorvida pelo corpo de prova, as seguintes energias não são levadas em consideração:

a) Energia absorvida pelo trabalho de deformação dos apoios verticais e o centro do percussor;

b) Energia absorvida pela fricção da peça ensaiada com os suportes, principalmente os apoios verticais.

\subsection{TESTE DA MÁQUINA DE ENSAIO DE IMPACTO}

\subsubsection{Teste para corpos de prova padrão}

Para a calibração da máquina de ensaio de impacto (MEI - 50) foram confeccionados, na Oficina Mecânica de Precisão da Prefeitura do Campus da USP de Ribeirão Preto, 128 corpos de prova Charpy - tipo C (FIGURA 1.1), extraídos de duas barras comerciais, uma de alumínio e outra de latão, e divididos em 2 grupos, sendo 64 peças em alumínio (Liga 6261) e as outras 64 em latão (Liga 360). Em seguida, cada grupo foi subdividido em 8 lotes de 8 peças.

Em uma máquina de ensaio de impacto HECKERT - PSd 300/150, com sistema de operação digital de leitura das energias absorvidas, do Departamento de Engenharia de Materiais, Aeronáutica e Automobilística da EESC - USP, foi ensaiado, de acordo com o padrão DIN, para corpos de prova Charpy - tipo C e distância entre os apoios de $40 \mathrm{~mm}$, o primeiro lote com 8 peças de alumínio e 8 de latão. Com a mesma quantidade de peças e obedecendo o mesmo padrão, o segundo lote foi ensaiado, numa máquina de ensaio de

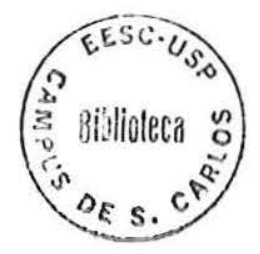


impacto HECKERT - 50, a qual opera por sistema analógico . Os demais lotes foram ensaiados na MEI - 50, no Laboratório de Bioengenharia da FMRP - USP, cujos resultados foram comparados aos dos dois primeiros lotes.

\subsubsection{Teste para material biológico}

Como teste de verificação da funcionabilidade da MEI - 50 para materiais biológicos, após a calibração através dos ensaios em corpos de prova metálicos, para materiais biológicos, foram ensaiadas tíbias inteiras de 10 coelhos albinos, machos, da raça Nova Zelândia, com peso corporal em torno de $2,5 \mathrm{~kg}$. Após o abate, as tíbias foram dissecadas, removidas as partes moles e levadas ao freezer à temperatura de $-20^{\circ} \mathrm{C}$; no dia anterior ao ensaio, foram retiradas e levadas ao refrigerador, envolvidas em gaze embebida em solução físiológica para se estabelecer o equilíbrio térmico.

Separadas aos pares, foram medidos seus comprimentos e as dimensões da secção diafísária média no sentido látero-medial e póstero-anterior. Levadas à máquina de impacto, foram posicionadas sobre os apoios, mantidos a distância de $40 \mathrm{~mm}$ de acordo com os padrões anteriores, e ensaiadas com a aplicação da carga no sentido ântero-posterior. 


\section{RESULTADOS}

\subsection{ENSAIOS DE AFERIÇÃO DA MÁQUINA DE ENSAIO DE IMPACTO}

Ensaiado na máquina de impacto HECKERT - PSd 300/150 o primeiro lote de 16 peças, constituído por $8 \mathrm{em}$ alumínio e 8 em latão, a energia absorvida média verificada foi de $(19,25 \pm 0,77)$ Joules para os corpos de prova em alumínio e, para os corpos de prova em latão, de $(18,41 \pm 0,65)$ Joules,. 0 segundo lote contendo também 8 peças em alumínio e 8 em latão foi ensaiado na máquina HECKERT - 50 , cujos valores obtidos determinaram uma energia absorvida média de $(19,46 \pm 0,63)$ Joules para os corpos de prova em alumínio e de $(16,88 \pm 0,82)$ Joules para o latão (TABELA 4.1). Estes resultados foram tomados como referenciais e comparados com os resultados obtidos nos ensaios realizados na MEI - $50 \mathrm{com}$ os lotes de 1 à 6 em alumínio e também de 1 à 6 em latão.

\subsubsection{Corpos de prova padrão em alumínio}

Os 48 corpos de prova restantes em alumínio foram divididos em 6 lotes de 8 peças e ensaiados na MEI - 50. A média da energia absorvida e o respectivo desvio padrão referentes aos ensaios realizados nestes 48 corpos de prova foi de $(19,85 \pm 0,75)$ Joules, (TABELA 4.1).

Analisando-se separadamente cada um dos lotes, a média da energia absorvida e o desvio padrão verificados, para cada lote ${ }^{3}$ de 8 peças, foram: lote $1,(20,03 \pm 0,69)$ Joules,

\footnotetext{
${ }^{3}$ Todas as tabelas referentes aos ensaios de cada lote estão em Anexos B.
} 
(TABELA B.1); lote 2, $(19,54 \pm 0,81)$ Joules, (TABELA B.2); lote 3, $(19,91 \pm 0,79)$ Joules, (TABELA B.3); lote 4, $(19,99 \pm 0,79)$ Joules, (TABELA B.4); lote 5, $(20,05 \pm 0,73)$ Joules, (TABELA B.5); lote 6, (19,50 \pm 0,77) Joules, (TABELA B.6).

\subsubsection{Corpos de prova padrão em latão}

Seguindo os mesmos padrões utilizados nos ensaios com corpos de prova em alumínio, os últimos 48 corpos de prova em latão foram divididos em 6 lotes de 8 peças cada e ensaiados na MEI - 50. A média da energia absorvida e o respectivo desvio padrão verificados nos ensaios dos 48 corpos de prova foi de $(18,00 \pm 0,69)$ Joules, (TABELA 4.1).

Analisando-se separadamente cada um dos lotes, a média da energia absorvida e o desvio padrão verificados nos ensaios foram: lote 1, $(18,64 \pm 0,77)$ Joules, (TABELA B.7); lote 2, $(17,79 \pm 0,66)$ Joules, (TABELA B.8); lote 3, $(18,13 \pm 0,76)$ Joules, (TABELA B.9); lote 4, $(17,78 \pm 0,86)$ Joules, (TABELA B.10); lote 5, $(17,91 \pm 0,81)$ Joules, (TABELA B.11); lote 6, (17,94 $\pm 0,73)$ Joules, (TABELA B.12).

Os valores das energias absorvidas por cada corpo de prova, nos ensaios para a calibração da MEI - 50, foram plotados e apresentados na seqüência em gráficos de dispersão ${ }^{4}$ para verificação do comportamento desta, os quais seguem as respectivas tabelas referentes a cada lote.

TABELA 4.1 - Médias e desvios padrão das energias absorvidas pelos corpos de prova.

\begin{tabular}{lccc}
\hline & $\begin{array}{c}\text { HECKERT PSd } \\
\mathbf{3 0 0 / 1 5 0}\end{array}$ & HECKERT - 50 & MEI - 50 \\
\hline N. ${ }^{\circ}$ de C. P. & 8 & 8 & 48 \\
ALUMíNIO & $(19,25 \pm 0,77)$ Joules & $(19,46 \pm 0,63)$ Joules & $(19,85 \pm 0,75)$ Joules \\
LATÃo & $(18,41 \pm 0,65)$ Joules & $(16,88 \pm 0,82)$ Joules & $(18,00 \pm 0,69)$ Joules \\
\hline
\end{tabular}

N. ${ }^{\circ}$ de C. P. - Número de corpos de prova.

\footnotetext{
${ }^{4}$ Todos os gráficos estão em Anexos B.
} 


\subsubsection{Material biológico}

As dimensões das tíbias e os respectivos valores das energias absorvidas medidas nos ensaios para verificação do funcionamento da MEI - 50, com aplicação de carga no sentido póstero-anterior foram: tíbias direitas de $(0,98 \pm 0,54)$ Joules; tíbias esquerdas de $(1,07 \pm 0,61)$ Joules, (TABELA 4.2).

TABELA 4.2 - Valores das energias absorvidas pelas tíbias, direitas e esquerdas, no ensaio de impacto realizado na máquina de ensaio de impacto (MEI - 50).

\begin{tabular}{ccccccc}
\hline Tíbia & $\mathrm{E}_{\mathrm{d}}(\mathrm{J})$ & $\mathrm{D}_{\mathrm{M}}(\mathrm{mm})$ & $\mathrm{D}_{\mathrm{m}}(\mathrm{mm})$ & $\mathrm{E}_{\mathrm{e}}(\mathrm{J})$ & $\mathrm{D}_{\mathrm{M}}(\mathrm{mm})$ & $\mathrm{D}_{\mathrm{m}}(\mathrm{mm})$ \\
\hline 1 & 0,4 & 8,6 & 5,6 & 1,4 & 8,1 & 5,5 \\
2 & 1,7 & 7,2 & 5,4 & 0,5 & 7,9 & 5,4 \\
3 & 1,6 & 8,5 & 6,3 & 1,1 & 8,6 & 6,1 \\
4 & 0,9 & 7,7 & 5,4 & 1,4 & 7,4 & 5,4 \\
5 & 0,6 & 8,6 & 5,6 & 1,9 & 8,8 & 5,5 \\
6 & 1,2 & 7,7 & 5,3 & 0,4 & 7,8 & 5,2 \\
7 & 0,5 & 8,0 & 5,6 & 1,3 & 8,1 & 5,6 \\
8 & 0,6 & 8,3 & 5,7 & 0,4 & 8,0 & 5,4 \\
9 & 0,5 & 8,4 & 5,9 & 0,4 & 8,2 & 5,7 \\
10 & 1,8 & 7,6 & 5,8 & 1,9 & 7,6 & 5,8 \\
\hline Média & 0,98 & 8,06 & 5,66 & 1,07 & 8,05 & 5,56 \\
D. P. & 0,54 & 0,49 & 0,29 & 0,61 & 0,42 & 0,25 \\
\hline
\end{tabular}

D. P. $\rightarrow$ Desvio Padrão 


\section{DISCUSSÃo}

Na calibração da máquina de ensaio de impacto (MEI - 50), através dos ensaios com corpos de prova padrão (TABELA 5.1), foi obtida uma boa precisão para o latão, apresentando um desvio percentual de $2,2 \%$ da $\mathrm{MEI}$ - 50 comparada à máquina de impacto HECKERT - PSd 300/150. O alumínio apresentou um desvio percentual de 3,1\% em relação a mesma máquina. Estes desvios entretanto não comprometem a calibração, pois estão dentro dos limites permitidos de variação das energias absorvidas pelos corpos de prova no ensaio de impacto. Com relação às máquinas MEI - 50 e HECKERT - 50, uma precisão também considerada como boa foi verificada, onde o alumínio apresentou um desvio percentual de $2,0 \%$ e de $6,6 \%$ para o latão, considerando que o limite de desvio percentual permitido é de $10 \%$, segundo NASSOUR $(1998)^{5}$.

TABELA 5.1 - Desvios percentuais das máquinas de impacto para os corpos de prova de alumínio e latão.

\begin{tabular}{cccc}
\hline & $\begin{array}{c}\text { HECKERT } \\
\text { PSd 300/150 }\end{array}$ & HECKERT - 50 & MEI - 50 \\
\hline $\begin{array}{c}\text { HECKERT } \\
\text { PSd 300/150 }\end{array}$ & - & $1,1 \%(\mathrm{Al})$ & $3,1 \%(\mathrm{Al})$ \\
HECKERT - 50 & $8,3 \%$ (Latão) & - & $2,0 \%$ (Al) \\
MEI - 50 & $2,2 \%$ (Latão) & 6,6\% (Latão) & - \\
\hline
\end{tabular}

Nos ensaios realizados em material biológico, verifícou-se o valor médio de energia absorvida de $0,98 \mathrm{~J}$ com desvio padrão de $0,54 \mathrm{~J}$ para as tíbias direitas e, para as tíbias esquerdas, $1,07 \mathrm{~J}$ o valor médio de energia absorvida com desvio padrão de $0,61 \mathrm{~J}$.

\footnotetext{
${ }^{5}$ NASSOUR, A. C. (1998). (USP. Escola de Engenharia de São Carlos. Departamento de Engenharia de Materiais, Aeronáutica e Automobilística). Comunicação pessoal.
} 
Estas variações devem-se, provavelmente, às diferenças nas propriedades geométricas e composição microestrutural das peças (ossos).

A intensificação das pesquisas científicas sobre as propriedades mecânicas dos ossos, a partir dos anos 60, vem justificar os estudos realizados por Galileu (1638), quando utilizou-se da Mecânica dos Corpos Rígidos em seus processos de análise.

Os ensaios realizados em ossos expõem uma certa complexidade devido às diferenças constatadas nas propriedades geométricas, mecânicas e microestruturais, ou seja, porque o osso é um material anisotrópico. Mesmo se o objetivo fosse confeccionar um corpo de prova com dimensões padronizadas, este dificilmente apresentaria as mesmas características, pois diferentes enfoques seriam dados na avaliação de tais propriedades. No caso dos materiais metálicos sua isotropia permite a congruência dos estudos relativos as suas propriedades mecânicas.

A influência da anisotropia dos ossos nos resultados dos ensaios de impacto pôde ser observada no ensaio realizado com tíbias de coelhos para a verificação do funcionamento da MEI -50, onde verificou-se uma dispersão de 55,1 \% para as tíbias direitas e 57,0 \% para as esquerdas nos valores de energia absorvida. Esta dispersão também foi observada por HERT et al. (1965), considerando que foram utilizados corpos de prova padronizados, retirados de ossos longos bovino, para realização do ensaio de impacto, mostrando assim que a dispersão na energia absorvida está diretamente relacionada com as características microestruturais dos ossos.

Apesar desta dispersão, o estudo das propriedades mecânicas de impacto dos ossos longos ajudará esclarecer tal comportamento, dando ênfase à necessidade de se eliminar suas variáveis geométricas (irregularidades) e estudar os componentes microestruturais (minerais, fibras de colágeno, porosidade e quantidade de água) para se determinar a relação de cada um, com as propriedades dinâmicas de impacto. Porém, através deste estudo foi possível verificar a facilidade de execução dos ensaios em materiais biológicos com a adaptação da distância entre os apoios de acordo com o osso a ser ensaiado, constituindo esta a diferença 
básica e importante com relação às máquinas de ensaio comerciais que utilizam distâncias padronizadas entre os apoios, dificultando a adaptação à estrutura biológica. Esta alteração da distância entre os apoios possibilita o estudo de diferentes tipos de ossos.

O estudo da resistência mecânica do tecido ósseo a cargas dinâmicas têm fundamental importância no entendimento do mecanismo de fratura femoral, principalmente junto ao quadril. COURTNEY et al. (1995) estudaram as mudanças na resistência femoral como um componente no aumento do risco de fratura do quadril. Os resultados obtidos com fêmures de cadáveres de indivíduos jovens e velhos, submetidos ao impacto na região proximal (trocanter maior), localizada junto ao quadril, mostraram que os fêmures dos indivíduos mais velhos tiveram metade da resistência dos fêmures dos indivíduos jovens, e absorveram um terço da energia. Com isto, tentaram explicar os motivos pelos quais as fraturas do quadril aumentam exponencialmente com a idade, sendo que $90 \%$ das fraturas do quadril ocorrem em indivíduos com mais de 70 anos de idade, e mais de $90 \%$ das fraturas são resultados de uma simples queda, constatando desta forma uma diminuição da resistência dos ossos ao impacto com passar dos anos.

O desenvolvimento do projeto e confecção da máquina de ensaio de impacto possibilitará ao Laboratório de Bioengenharia da FMRP-USP apoiar futuros trabalhos na área de ensaios dinâmicos. 


\section{CONCLUSÃO}

Os testes de verifícação do funcionamento e calibração da máquina de ensaio de impacto apresentaram resultados muito satisfatórios, comprovando a validade dos objetivos, justificando a proposta de variação das distâncias entre os apoios e dos métodos construtivos empregados. No entanto, foi signifícativa a dispersão observada no ensaio com material biológico, o que revela a necessidade de se ter cautela no uso do ensaio de impacto para caracterizar a resistência mecânica dos materiais biológicos quando submetidos à cargas dinâmicas. 


\section{SUGESTÕES PARA FUTUROS TRABALHOS}

O desenvolvimento de máquinas projetadas especialmente para ensaio de materiais biológicos e, também, ensaios de ossos intactos, sem a remoção dos tecidos moles, para averiguação de suas influências como elementos absorvedores de energia, possibilitando também o entendimento da dispersão verificada nas medidas realizadas neste trabalho. 
ANEXOS A

Em anexo estão relacionados todos os desenhos referentes às partes componentes da máquina de ensaio de impacto, objeto deste trabalho. 


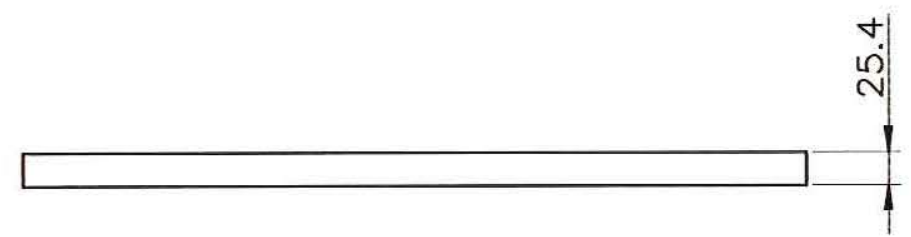

VISTA FRONTAL

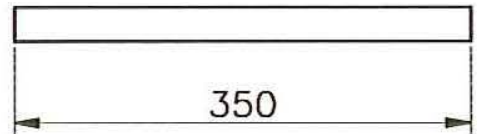

VISTA LATERAL

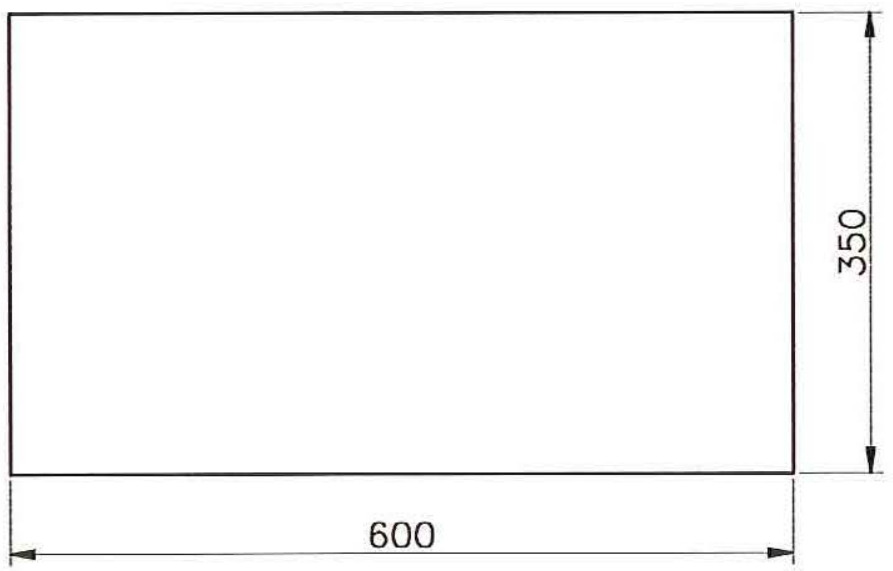

VISTA SUPERIOR

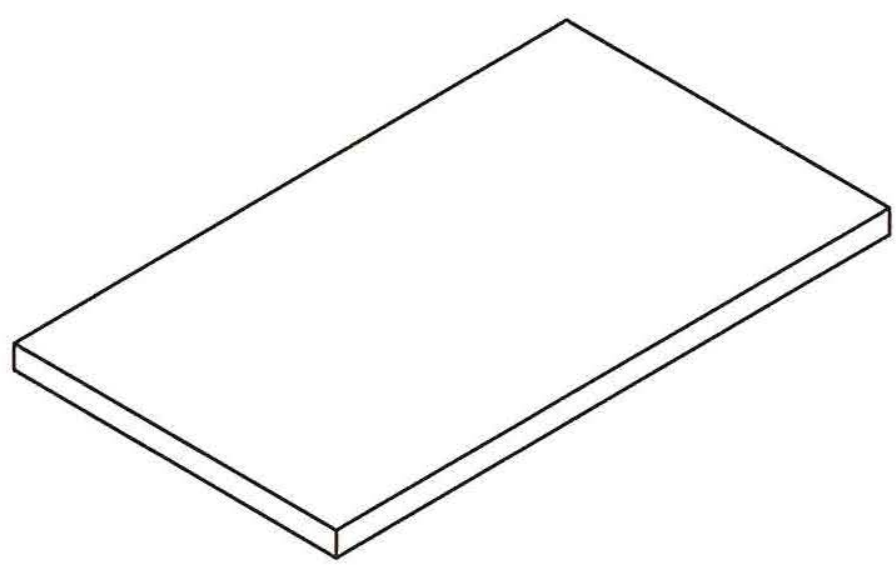

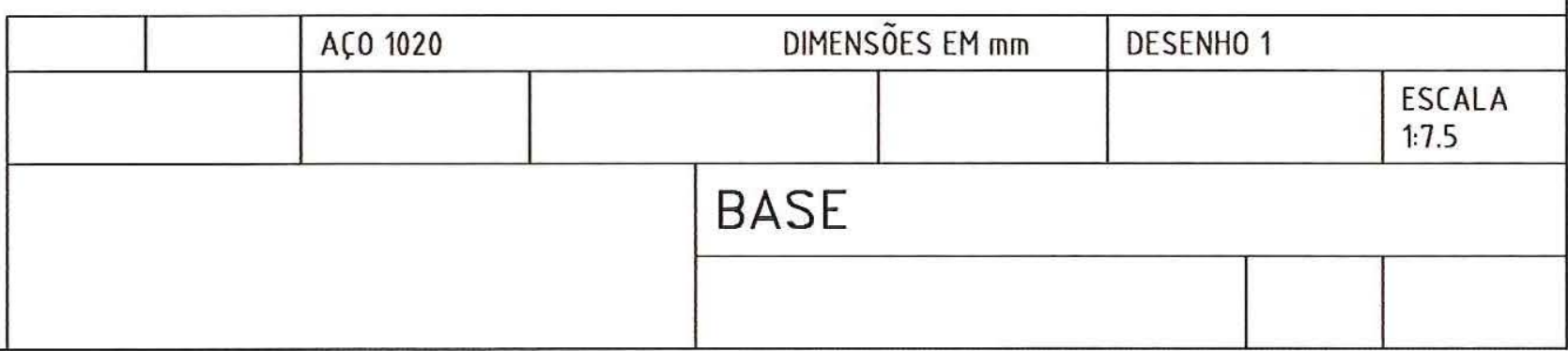




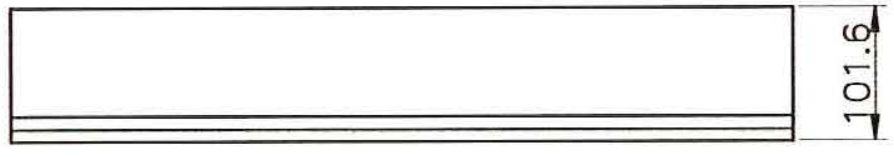

VISTA FRONTAL

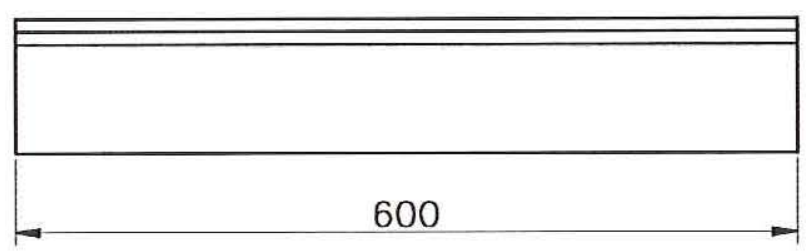

VISTA SUPERIOR

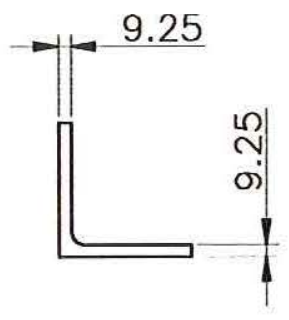

VISTA LATERAL

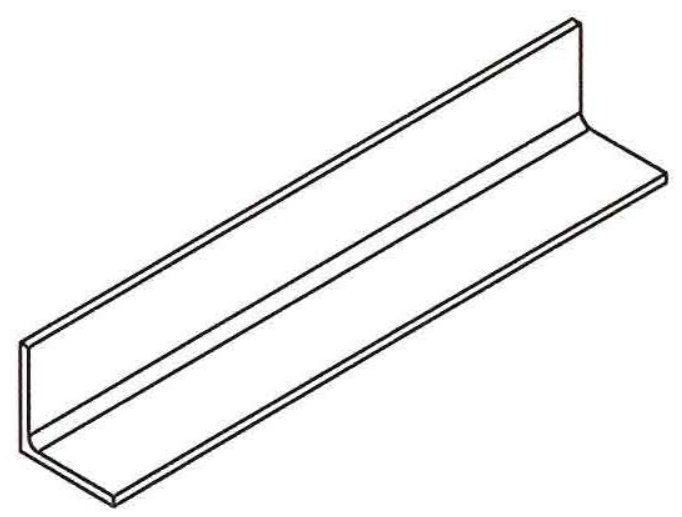

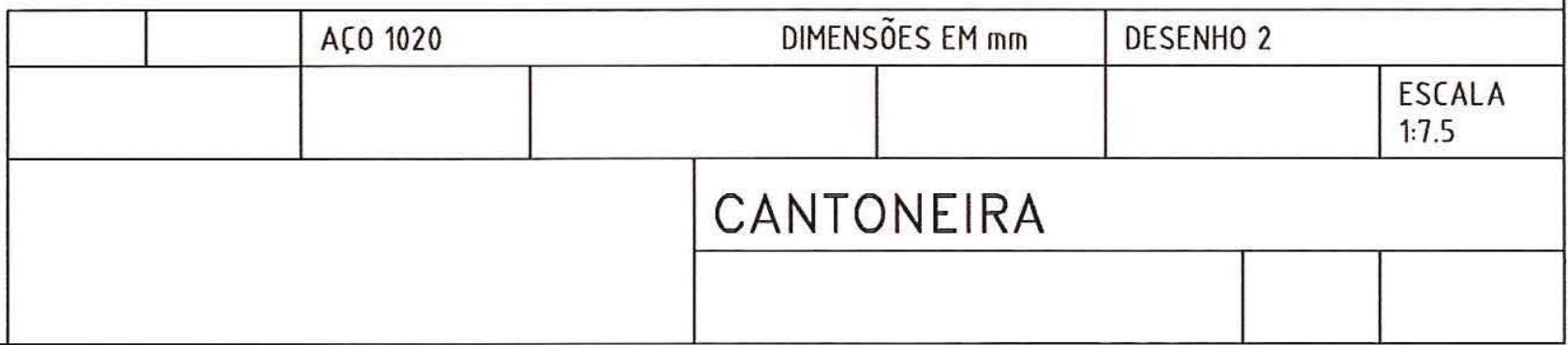




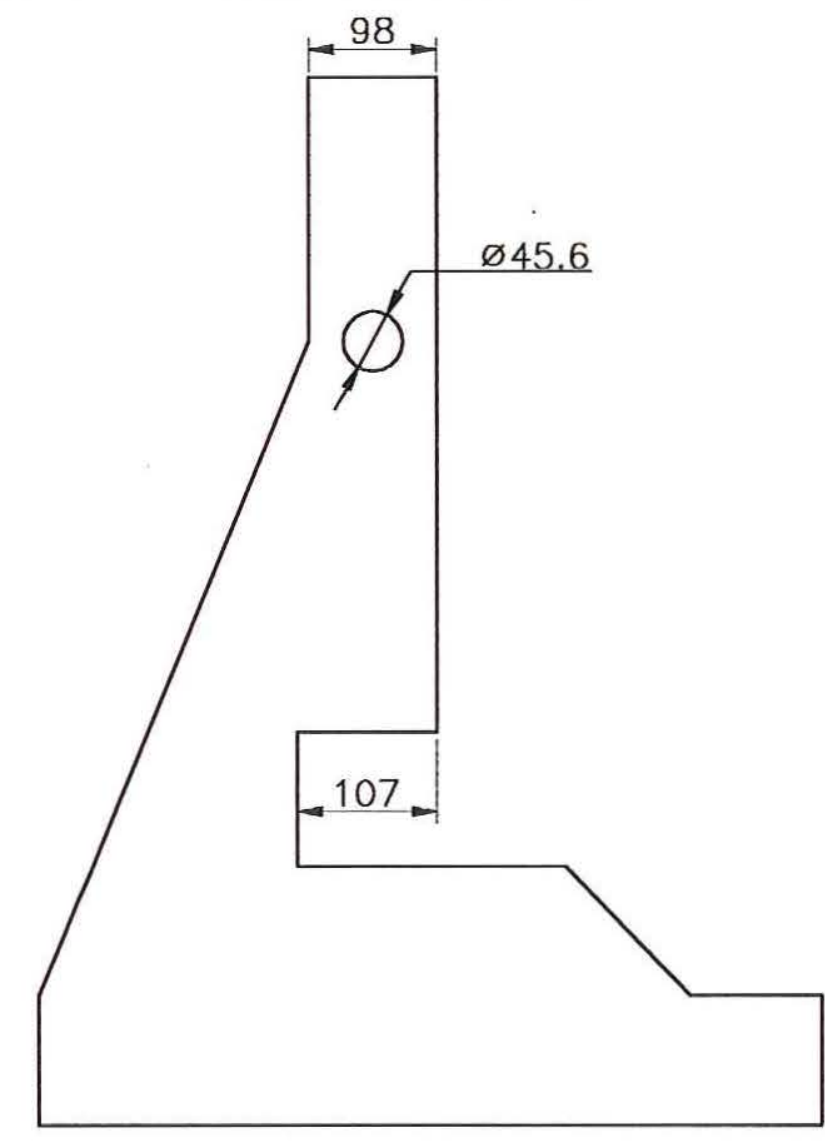

VISTA FRONTAL

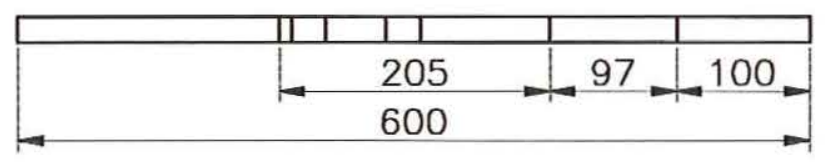

VISTA SUPERIOR
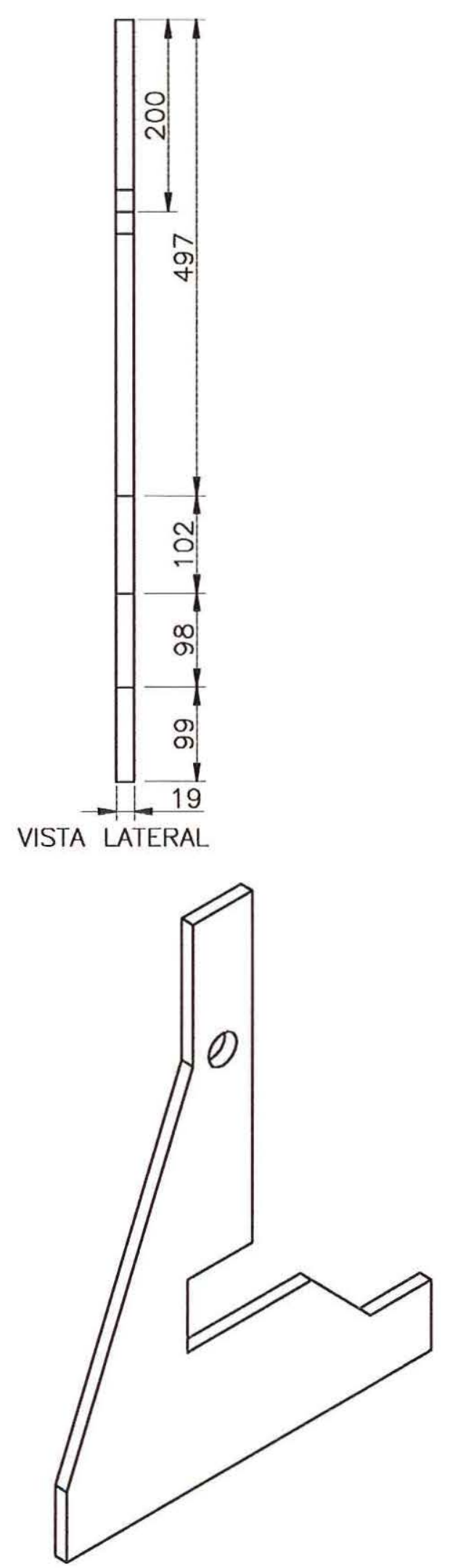

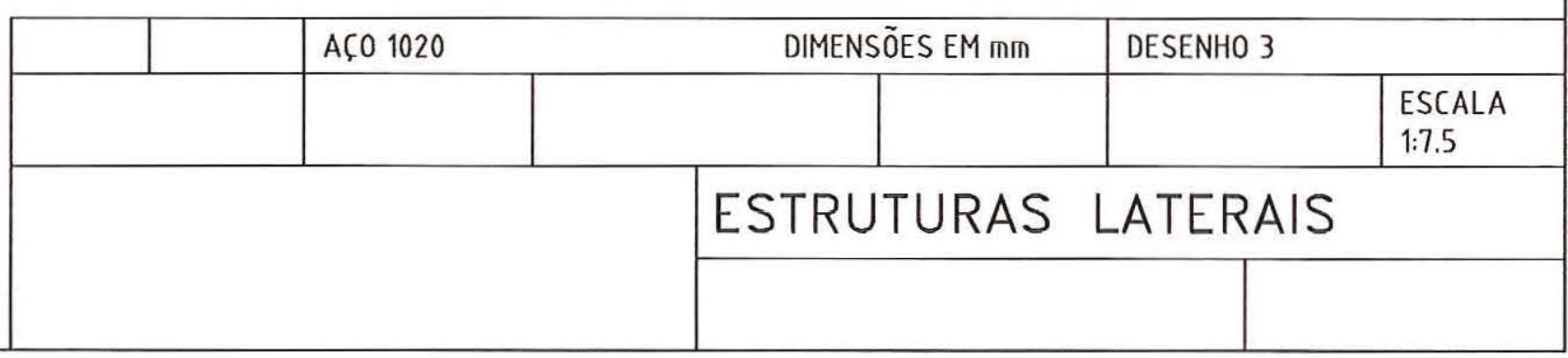




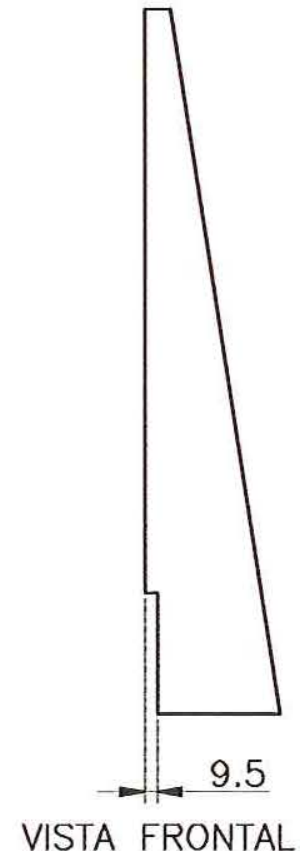

VISTA FRONTAL

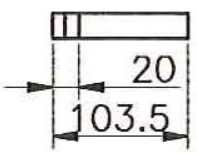

VISTA SUPERIOR

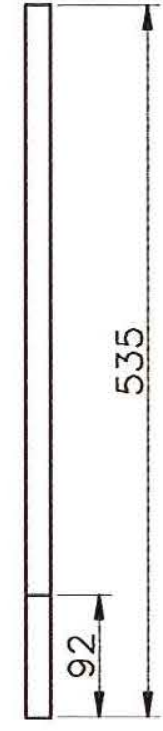

VISTA LATERAL

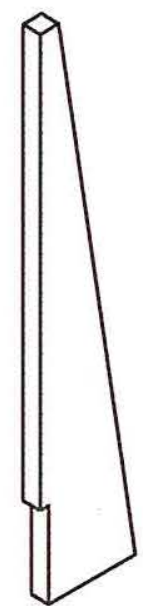

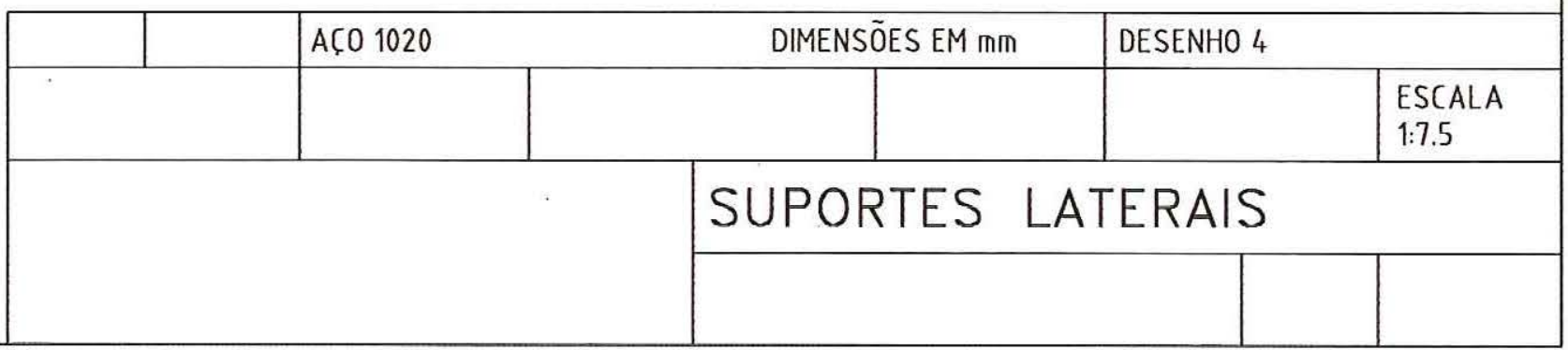



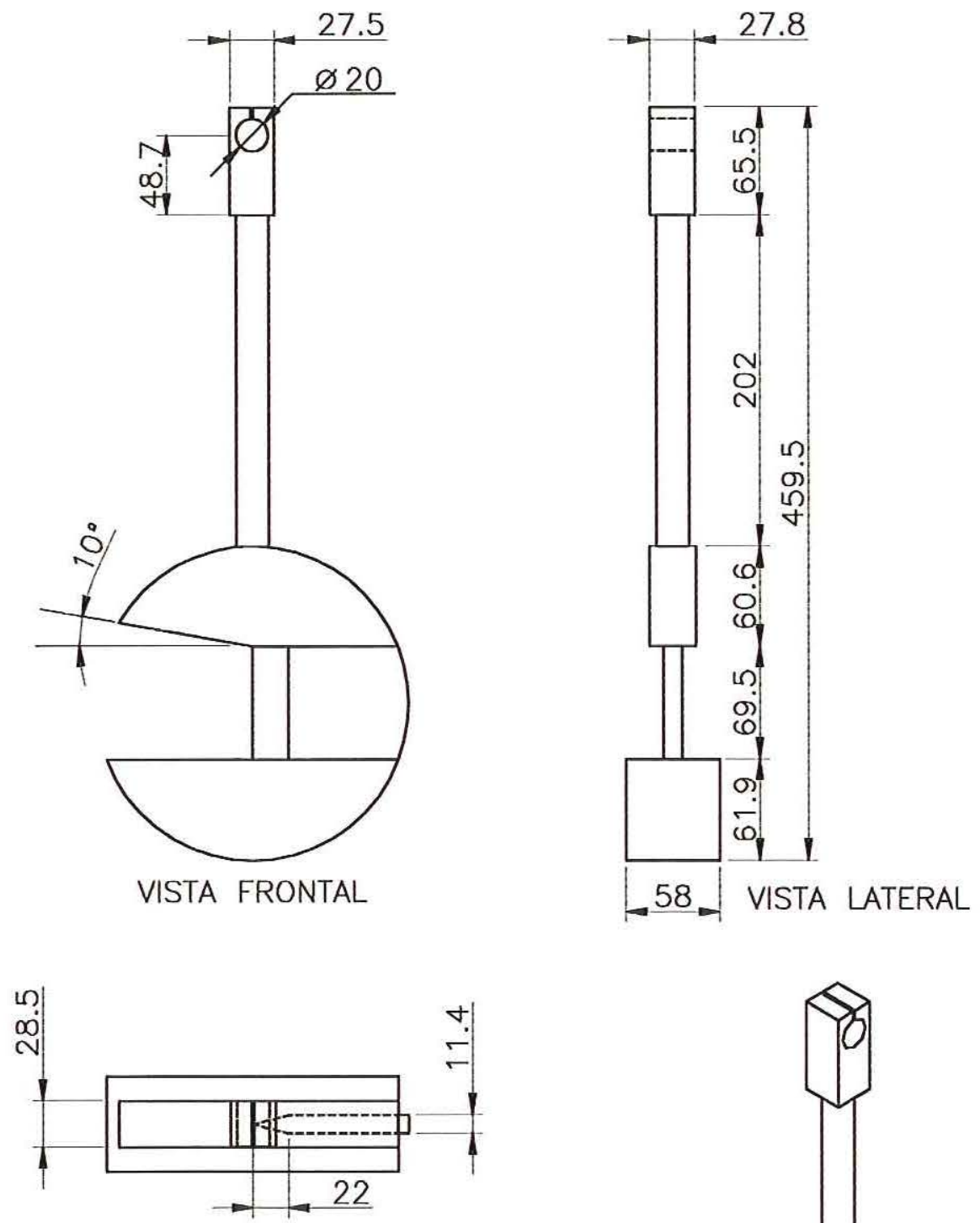

VISTA SUPERIOR

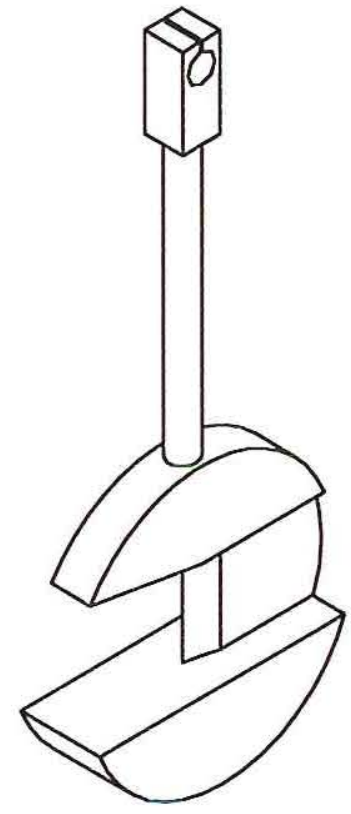

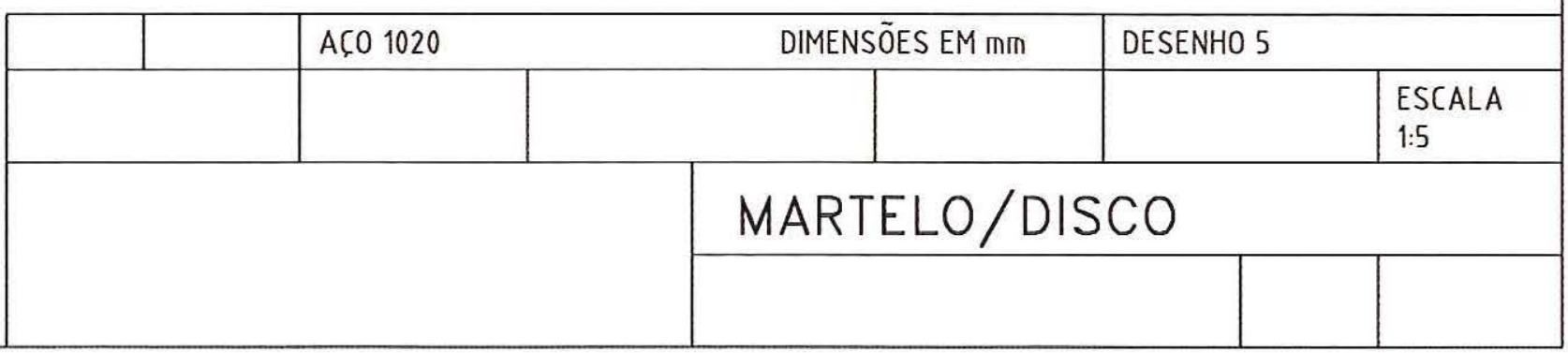



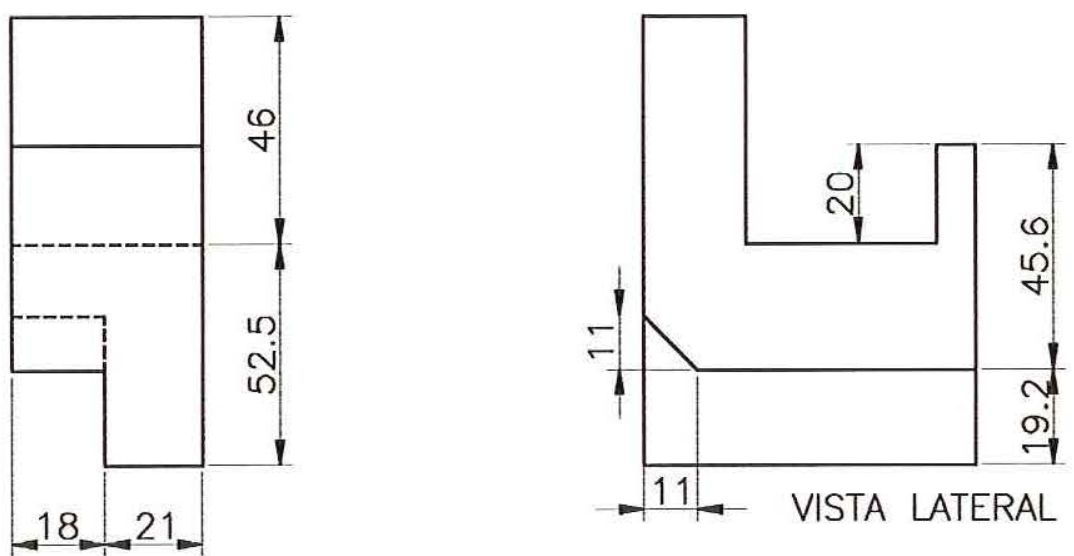

VISTA FRONTAL
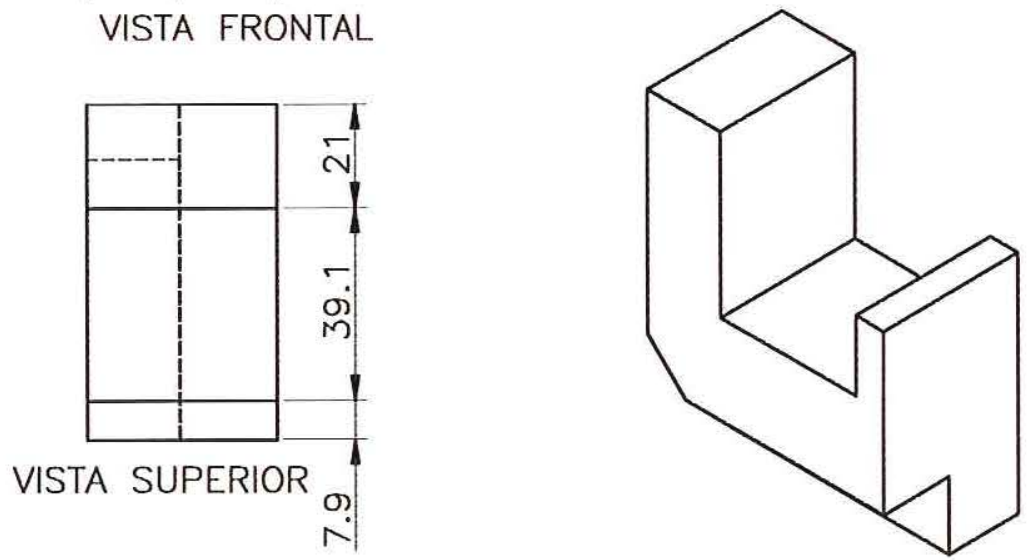

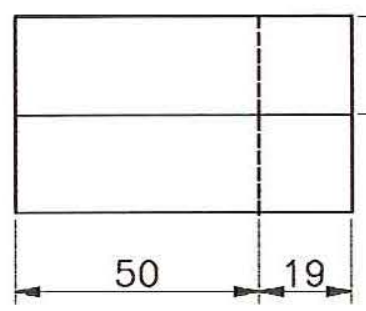

VISTA FRONTAL

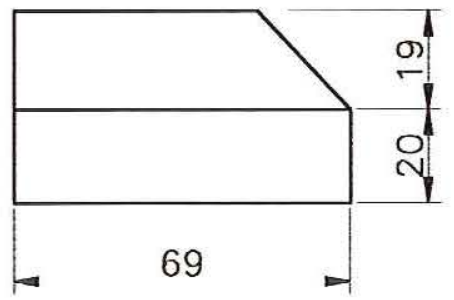

VISTA SUPERIOR

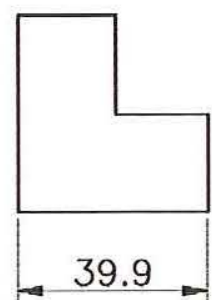

VISTA LATERAL

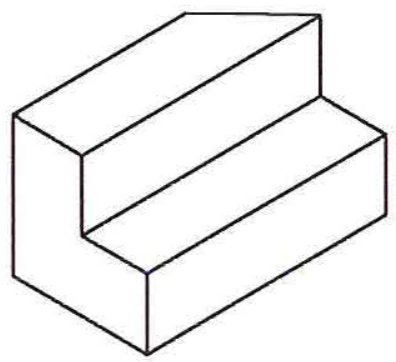

DIMENSÕES EM mm

DESENHO 6 $1: 2$

SUPORTES E APOIOS DO CORPO DE PROVA 


\section{ANEXOS B}

Em anexo estão as tabelas e gráficos com os valores das energias absorvidas por cada corpo de prova em alumínio e latão. 
TABELA B.1 - Valores das energias absorvidas medidas nos ensaios de impacto do Lote 1 de corpos de prova em alumínio.

\begin{tabular}{cccc}
\hline & HECKERT - PSd 300/150 & HECKERT - 50 & MEI - 50 \\
\hline & Energia Absorvida (J) & Energia Absorvida (J) & Energia Absorvida (J) \\
1 & 17,9 & 19,1 & 20,6 \\
2 & 18,7 & 20,8 & 19,3 \\
3 & 20,4 & 19,6 & 19,7 \\
4 & 19,2 & 18,7 & 20,2 \\
5 & 20,0 & 19,0 & 21,3 \\
6 & 19,2 & 19,5 & 19,8 \\
7 & 19,6 & 19,5 & 19,2 \\
8 & 19,0 & 19,5 & 20,1 \\
\hline Média & 19,25 & 19,46 & 20,03 \\
D.P. & 0,77 & 0,63 & 0,69 \\
\hline
\end{tabular}

D. P. $\rightarrow$ Desvio Padrão

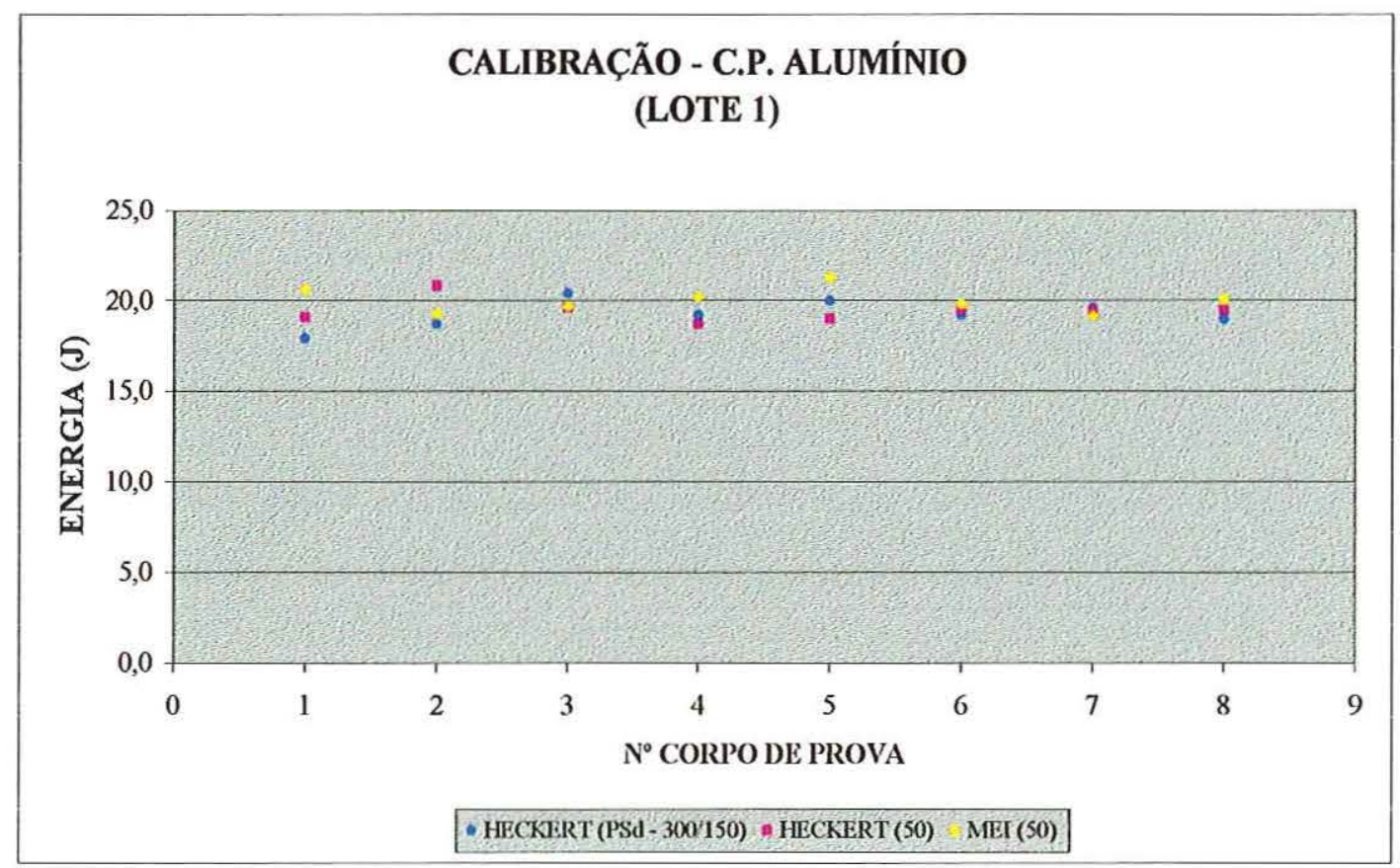

FIGURA B.1 - Gráfico de calibração da máquina de impacto utilizando corpos de prova em alumínio, referente à TABELA B.1. 
TABELA B.2 - Valores das energias absorvidas medidas nos ensaios de impacto do Lote 2 de corpos de prova em alumínio.

\begin{tabular}{cccc}
\hline & HECKERT - PSd 300/150 & HECKERT - 50 & MEI - 50 \\
\hline & Energia Absorvida (J) & Energia Absorvida (J) & Energia Absorvida (J) \\
1 & 17,9 & 19,1 & 19,8 \\
2 & 18,7 & 20,8 & 19,5 \\
3 & 20,4 & 19,6 & 20,0 \\
4 & 19,2 & 18,7 & 19,7 \\
5 & 20,0 & 19,0 & 19,2 \\
6 & 19,2 & 19,5 & 18,7 \\
7 & 19,6 & 19,5 & 21,2 \\
8 & 19,0 & 19,5 & 19,0 \\
\hline Média & 19,25 & 19,46 & 19,54 \\
D.P. & 0,77 & 0,63 & 0,81 \\
\hline
\end{tabular}

D. P. $\rightarrow$ Desvio Padrão

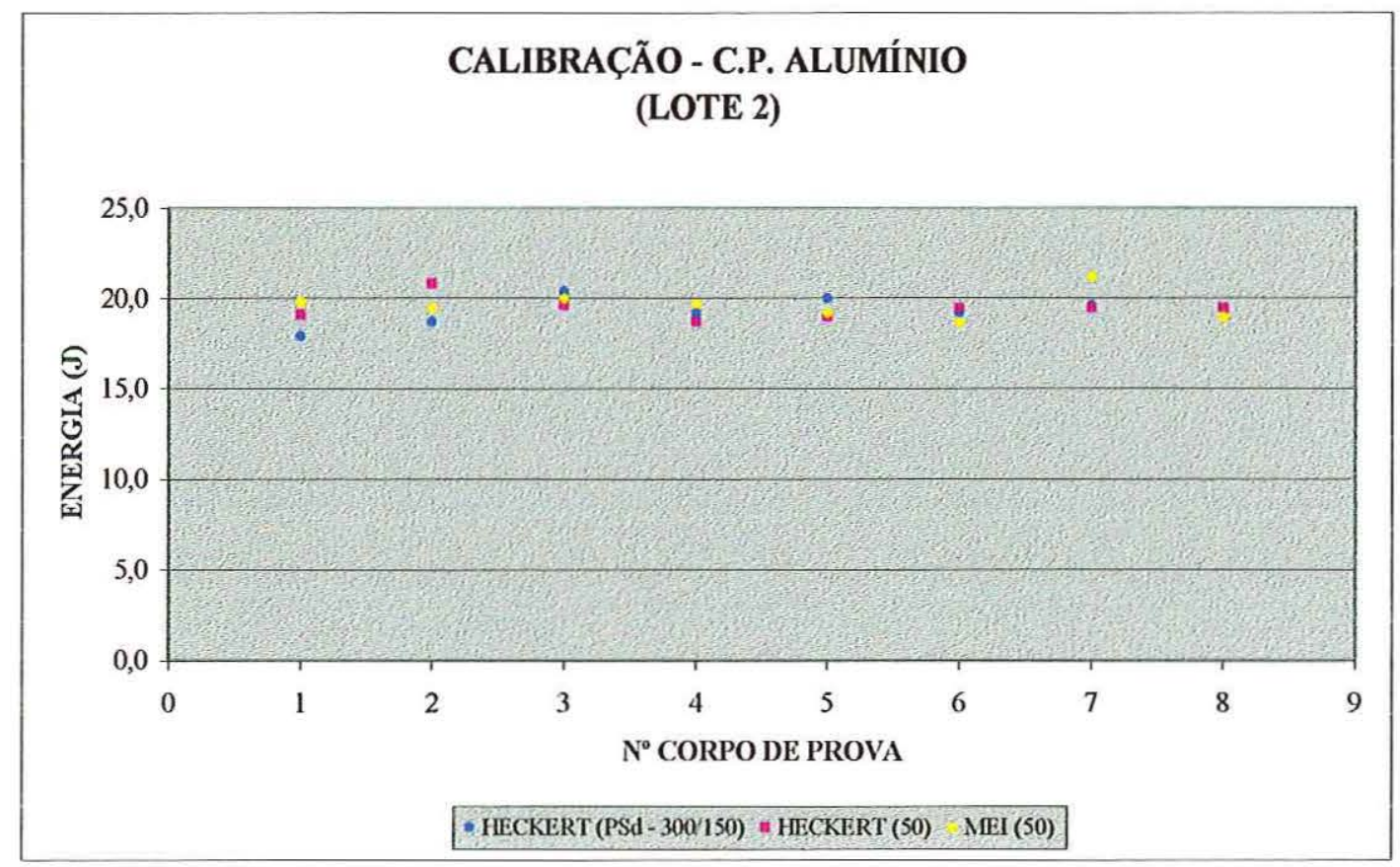

FIGURA B.2 - Gráfico de calibração da máquina de impacto utilizando corpos de prova em alumínio, referente à TABELA B.2. 
TABELA B.3 - Valores das energias absorvidas medidas nos ensaios de impacto do Lote 3 de corpos de prova em alumínio.

\begin{tabular}{cccc}
\hline & HECKERT - PSd 300/150 & HECKERT - 50 & MEI - 50 \\
\hline & Energia Absorvida (J) & Energia Absorvida (J) & Energia Absorvida (J) \\
1 & 17,9 & 19,1 & 20,2 \\
2 & 18,7 & 20,8 & 19,7 \\
3 & 20,4 & 19,6 & 19,9 \\
4 & 19,2 & 18,7 & 19,2 \\
5 & 20,0 & 19,0 & 18,8 \\
6 & 19,2 & 19,5 & 21,0 \\
7 & 19,6 & 19,5 & 19,5 \\
8 & 19,0 & 19,5 & 21,0 \\
\hline Média & 19,25 & 19,46 & 19,91 \\
D.P. & 0,77 & 0,63 & 0,79 \\
\hline
\end{tabular}

D. P. $\rightarrow$ Desvio Padrão

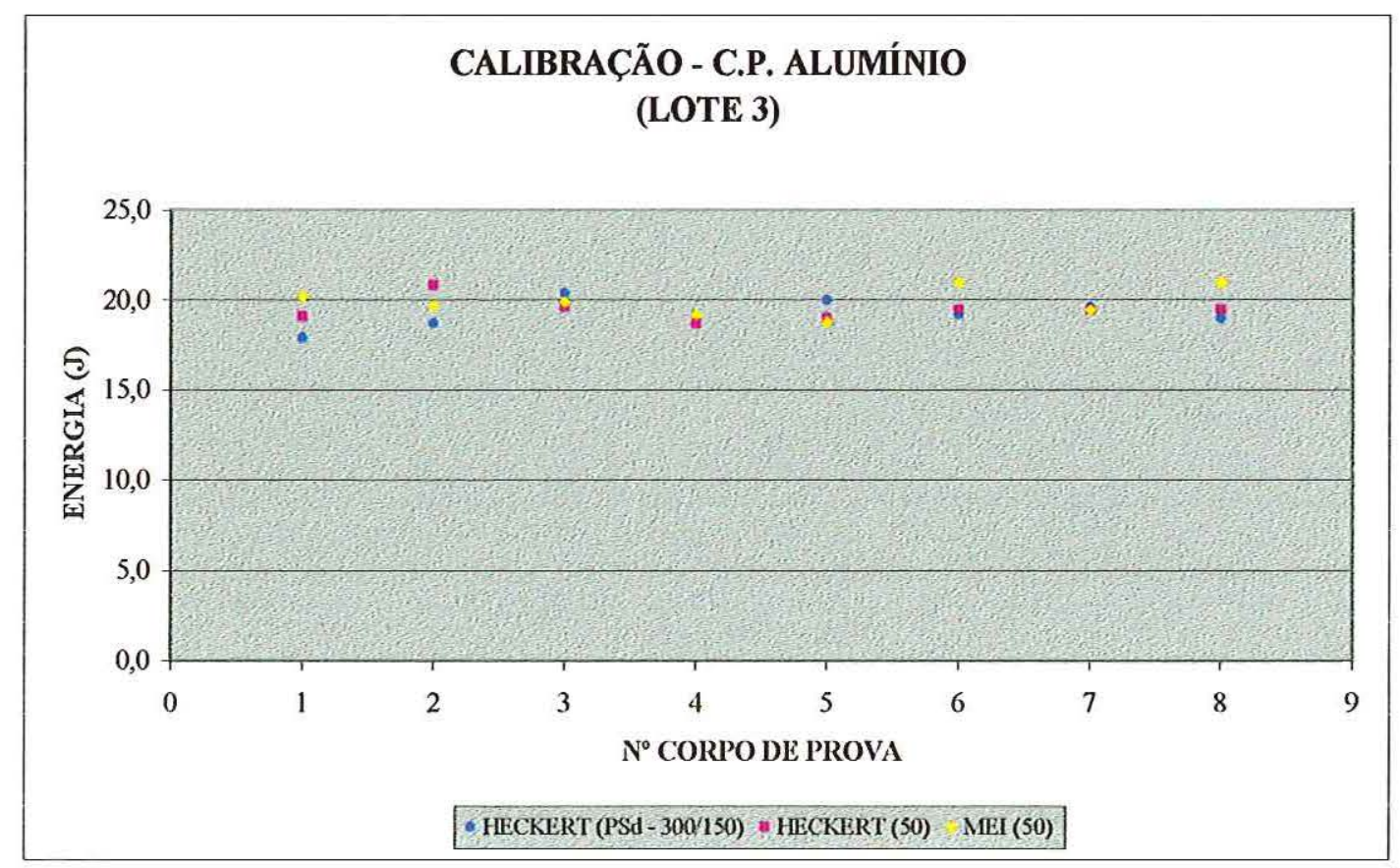

FIGURA B.3 - Gráfico de calibração da máquina de impacto utilizando corpos de prova em alumínio, referente à TABELA B.3. 
TABELA B.4 - Valores das energias absorvidas medidas nos ensaios de impacto do Lote 4 de corpos de prova em alumínio.

\begin{tabular}{cccc}
\hline & HECKERT - PSd 300/150 & HECKERT - 50 & MEI - 50 \\
\hline & Energia Absorvida (J) & Energia Absorvida (J) & Energia Absorvida (J) \\
1 & 17,9 & 19,1 & 19,5 \\
2 & 18,7 & 20,8 & 19,8 \\
3 & 20,4 & 19,6 & 18,9 \\
4 & 19,2 & 18,7 & 21,0 \\
5 & 20,0 & 19,0 & 19,8 \\
6 & 19,2 & 19,5 & 19,7 \\
7 & 19,6 & 19,5 & 21,3 \\
8 & 19,0 & 19,5 & 19,9 \\
\hline Média & 19,25 & 19,46 & 19,99 \\
D.P. & 0,77 & 0,63 & 0,79 \\
\hline
\end{tabular}

D. P. $\rightarrow$ Desvio Padrão

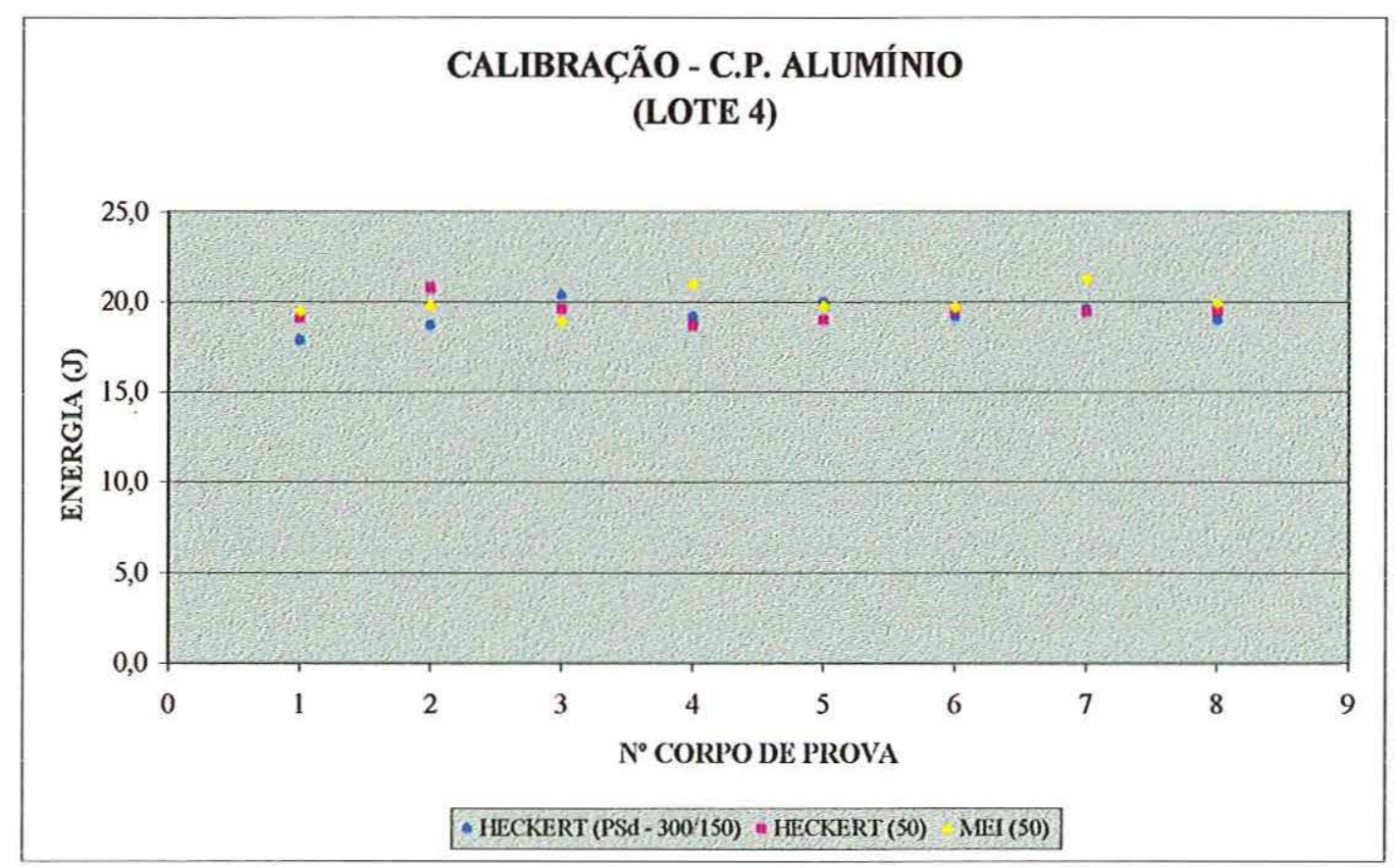

FIGURA B.4 - Gráfico de calibração da máquina de impacto utilizando corpos de prova em alumínio, referente à TABELA B.4. 
TABELA B.5 - Valores das energias absorvidas medidas nos ensaios de impacto do Lote 5 de corpos de prova em alumínio.

\begin{tabular}{cccc}
\hline & HECKERT - PSd 300/150 & HECKERT - 50 & MEI - 50 \\
\hline & Energia Absorvida (J) & Energia Absorvida (J) & Energia Absorvida (J) \\
1 & 17,9 & 19,1 & 20,6 \\
2 & 18,7 & 20,8 & 19,5 \\
3 & 20,4 & 19,6 & 19,6 \\
4 & 19,2 & 18,7 & 20,2 \\
5 & 20,0 & 19,0 & 19,7 \\
6 & 19,2 & 19,5 & 21,5 \\
7 & 19,6 & 19,5 & 19,2 \\
8 & 19,0 & 19,5 & 20,1 \\
\hline Média & 19,25 & 19,46 & 20,05 \\
D.P. & 0,77 & 0,63 & 0,73 \\
\hline
\end{tabular}

D. P. $\rightarrow$ Desvio Padrão

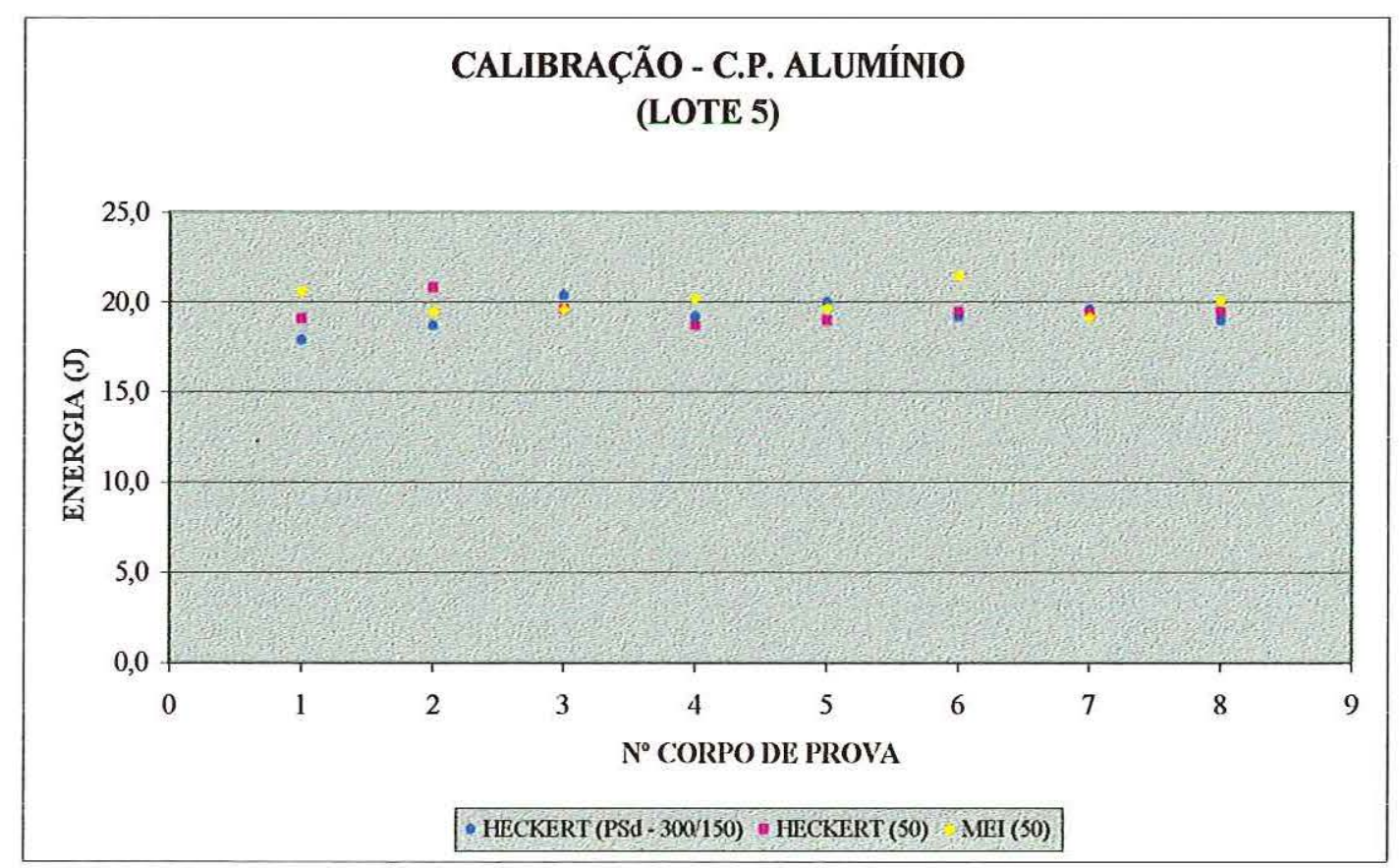

FIGURA B.5 - Gráfico de calibração da máquina de impacto utilizando corpos de prova em alumínio, referente à TABELA B.5. 
TABELA B.6 - Valores das energias absorvidas medidas nos ensaios de impacto do Lote 6 de corpos de prova em alumínio.

\begin{tabular}{cccc}
\hline & HECKERT - PSd 300/150 & HECKERT - 50 & MEI - 50 \\
\hline & Energia Absorvida (J) & Energia Absorvida (J) & Energia Absorvida (J) \\
1 & 17,9 & 19,1 & 18,6 \\
2 & 18,7 & 20,8 & 19,5 \\
3 & 20,4 & 19,6 & 20,2 \\
4 & 19,2 & 18,7 & 20,5 \\
5 & 20,0 & 19,0 & 19,4 \\
6 & 19,2 & 19,5 & 19,8 \\
7 & 19,6 & 19,5 & 18,2 \\
8 & 19,0 & 19,5 & 19,8 \\
\hline Média & 19,25 & 19,46 & 19,50 \\
D.P. & 0,77 & 0,63 & 0,77 \\
\hline
\end{tabular}

D. P. $\rightarrow$ Desvio Padrão

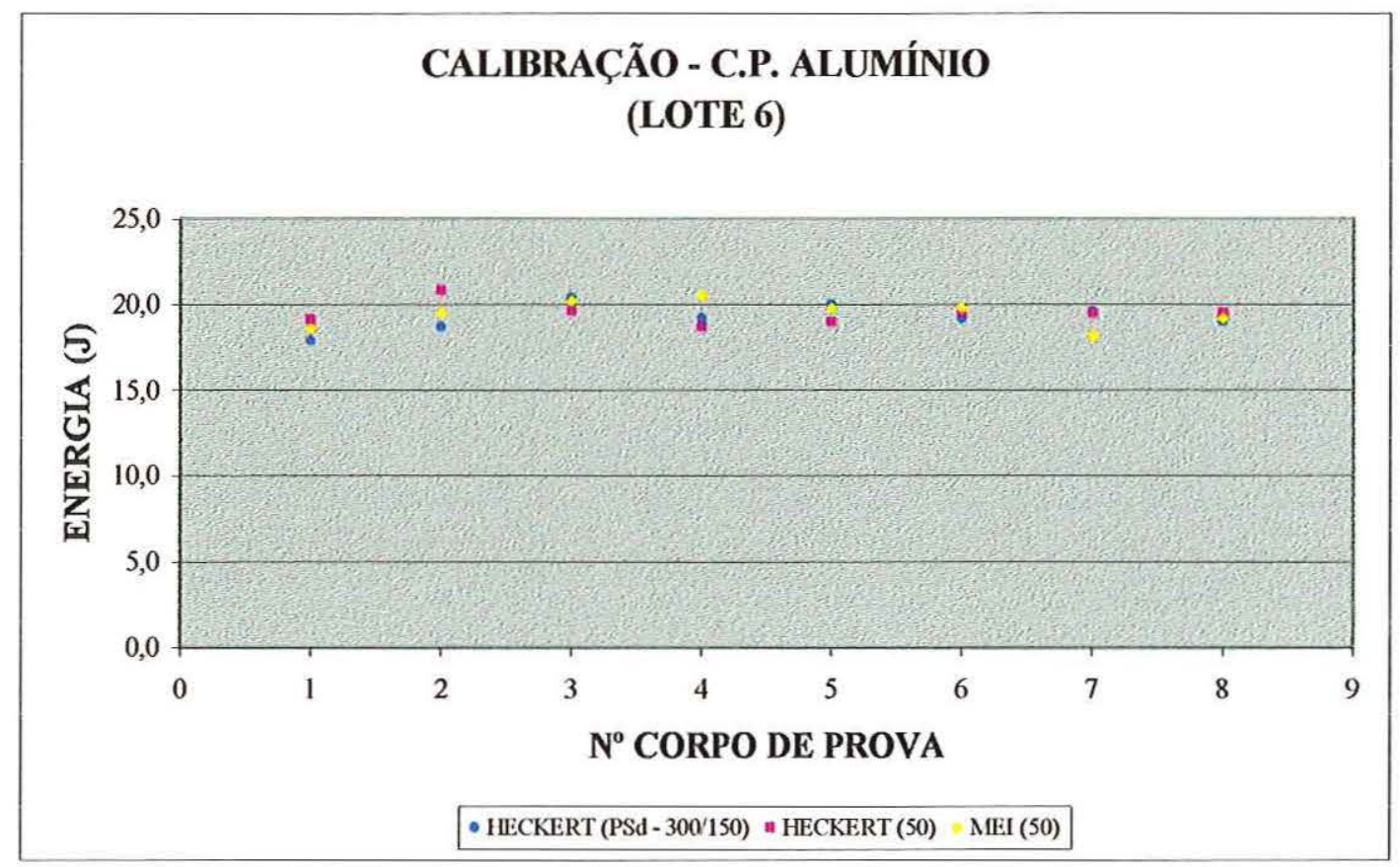

FIGURA B.6 - Gráfico de calibração da máquina de impacto utilizando corpos de prova em alumínio, referente à TABELA B.6. 
TABELA B.7 - Valores das energias absorvidas medidas nos ensaios de impacto do Lote 1 de corpos de prova em latão.

\begin{tabular}{cccc}
\hline & HECKERT - PSd 300/150 & HECKERT - 50 & MEI - 50 \\
\hline & Energia Absorvida (J) & Energia Absorvida (J) & Energia Absorvida (J) \\
1 & 19,0 & 16,6 & 19,0 \\
2 & 18,9 & 17,5 & 19,2 \\
3 & 18,5 & 17,1 & 18,2 \\
4 & 17,5 & 16,7 & 19,6 \\
5 & 17,3 & 17,5 & 18,3 \\
6 & 18,5 & 16,1 & 17,5 \\
7 & 18,7 & 15,5 & 17,9 \\
8 & 18,9 & 18,0 & 19,4 \\
\hline Média & 18,41 & 16,88 & 18,64 \\
D.P. & 0,65 & 0,82 & 0,77 \\
\hline
\end{tabular}

D. P. $\rightarrow$ Desvio Padrão

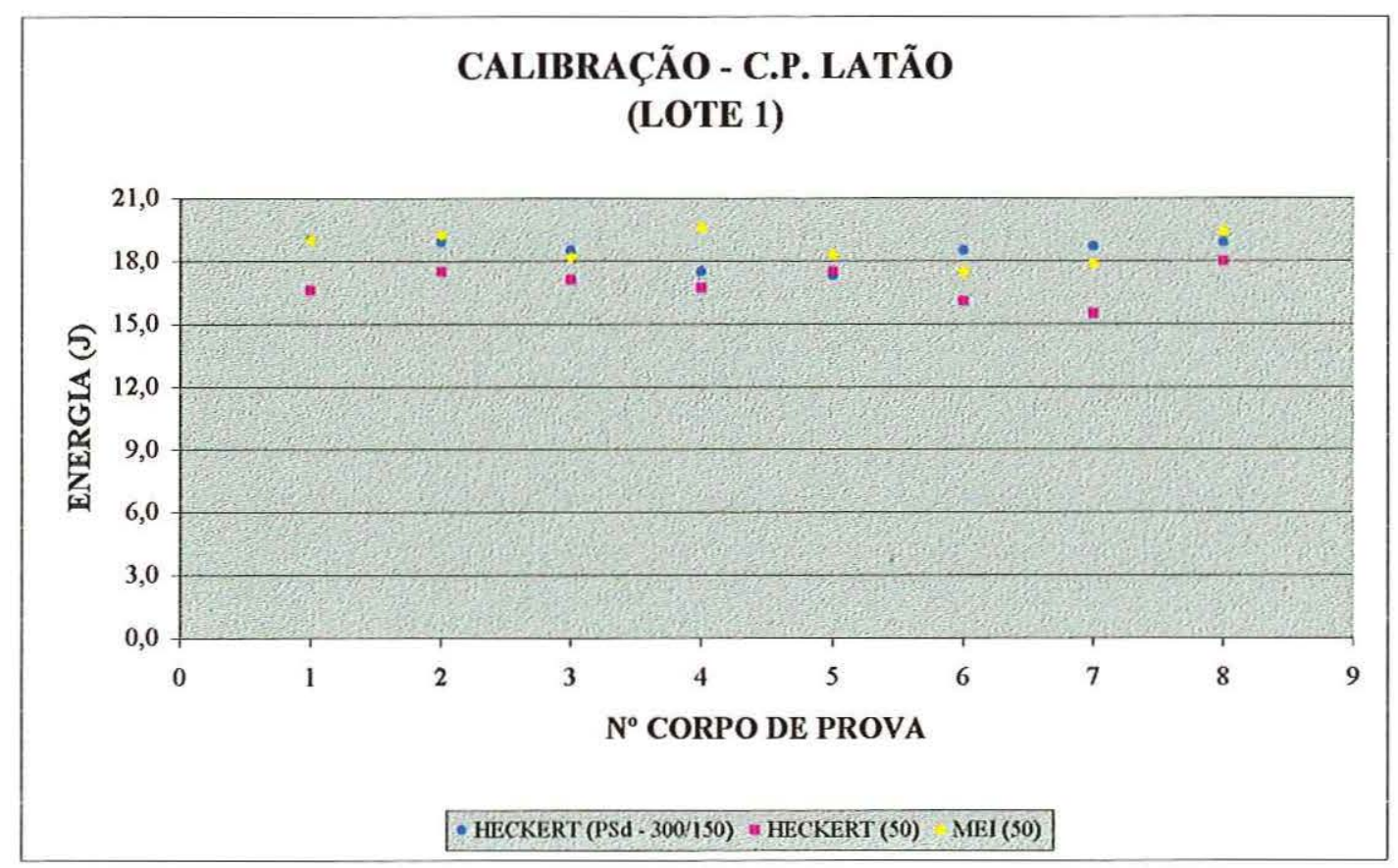

FIGURA B.7 - Gráfico de calibração da máquina de impacto utilizando corpos de prova em latão, referente à TABELA B.7.

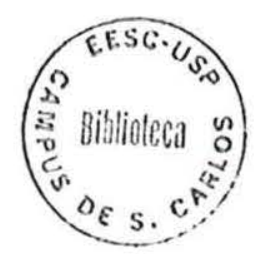


TABELA B.8 - Valores das energias absorvidas medidas nos ensaios de impacto do Lote 2 de corpos de prova em latão.

\begin{tabular}{cccc}
\hline & HECKERT - PSd 300/150 & HECKERT - 50 & MEI - 50 \\
\hline & Energia Absorvida (J) & Energia Absorvida (J) & Energia Absorvida (J) \\
1 & 19,0 & 16,6 & 18,5 \\
2 & 18,9 & 17,5 & 17,3 \\
3 & 18,5 & 17,1 & 18,2 \\
4 & 17,5 & 16,7 & 18,5 \\
5 & 17,3 & 17,5 & 16,8 \\
6 & 18,5 & 16,1 & 18,3 \\
7 & 18,7 & 15,5 & 17,2 \\
8 & 18,9 & 18,0 & 17,5 \\
\hline Média & 18,41 & 16,88 & 17,79 \\
D.P. & 0,65 & 0,82 & 0,66 \\
\hline
\end{tabular}

D. P. $\rightarrow$ Desvio Padrão

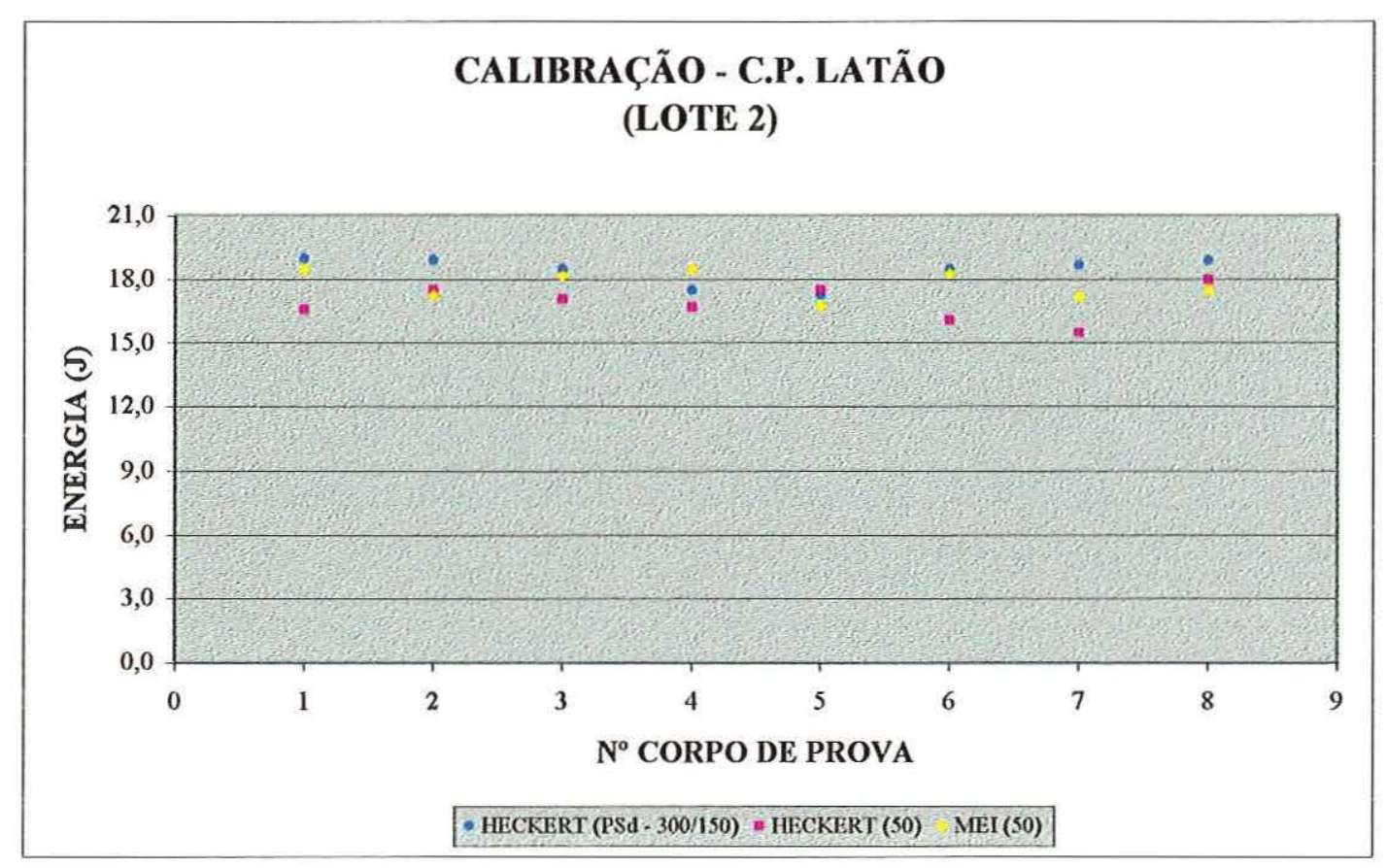

FIGURA B.8 - Gráfico de calibração da máquina de impacto utilizando corpos de prova em latão, referente à TABELA B.8. 
TABELA B.9 - Valores das energias absorvidas medidas nos ensaios de impacto do Lote 3 de corpos de prova em latão.

\begin{tabular}{cccc}
\hline & HECKERT - PSd 300/150 & HECKERT - 50 & MEI - 50 \\
\hline & Energia Absorvida (J) & Energia Absorvida (J) & Energia Absorvida (J) \\
1 & 19,0 & 16,6 & 17,5 \\
2 & 18,9 & 17,5 & 18,2 \\
3 & 18,5 & 17,1 & 17,9 \\
4 & 17,5 & 16,7 & 19,2 \\
5 & 17,3 & 17,5 & 18,6 \\
6 & 18,5 & 16,1 & 18,9 \\
7 & 18,7 & 15,5 & 16,9 \\
8 & 18,9 & 18,0 & 17,8 \\
\hline Média & 18,41 & 16,88 & 18,13 \\
D.P. & 0,65 & 0,82 & 0,76 \\
\hline
\end{tabular}

D. P. $\rightarrow$ Desvio Padrão

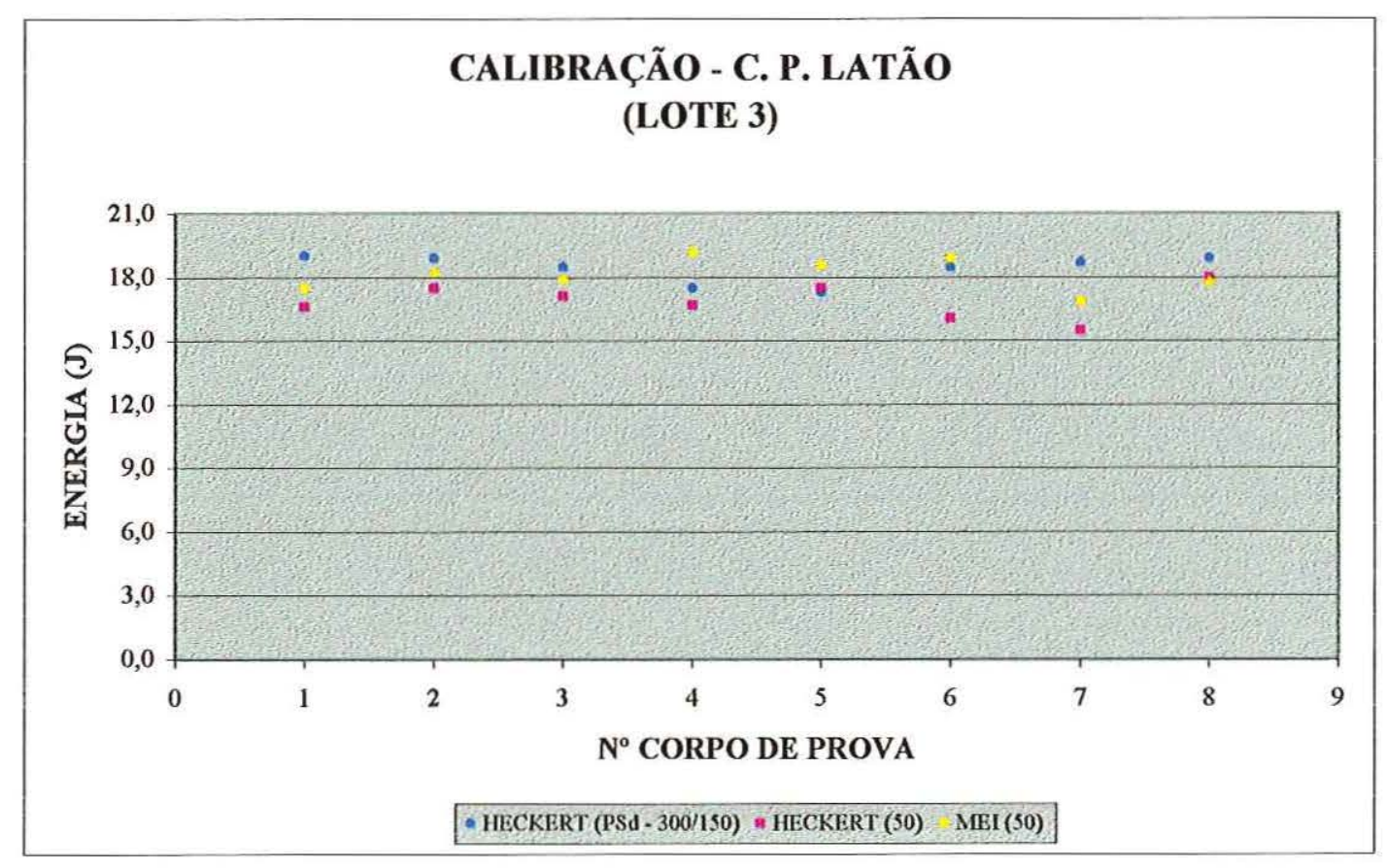

FIGURA B.9 - Gráfico de calibração da máquina de impacto utilizando corpos de prova em latão, referente à TABELA B.9. 
TABELA B.10 - Valores das energias absorvidas medidas nos ensaios de impacto do Lote 4 de corpos de prova em latão.

\begin{tabular}{cccc}
\hline & HECKERT - PSd 300/150 & HECKERT - 50 & MEI - 50 \\
\hline & Energia Absorvida (J) & Energia Absorvida (J) & Energia Absorvida (J) \\
1 & 19,0 & 16,6 & 19,2 \\
2 & 18,9 & 17,5 & 17,3 \\
3 & 18,5 & 17,1 & 18,1 \\
4 & 17,5 & 16,7 & 17,8 \\
5 & 17,3 & 17,5 & 16,7 \\
6 & 18,5 & 16,1 & 18,7 \\
7 & 18,7 & 15,5 & 17,5 \\
8 & 18,9 & 18,0 & 16,9 \\
\hline Média & 18,41 & 16,88 & 17,78 \\
D.P. & 0,65 & 0,82 & 0,86 \\
\hline
\end{tabular}

D. P. $\rightarrow$ Desvio Padrão

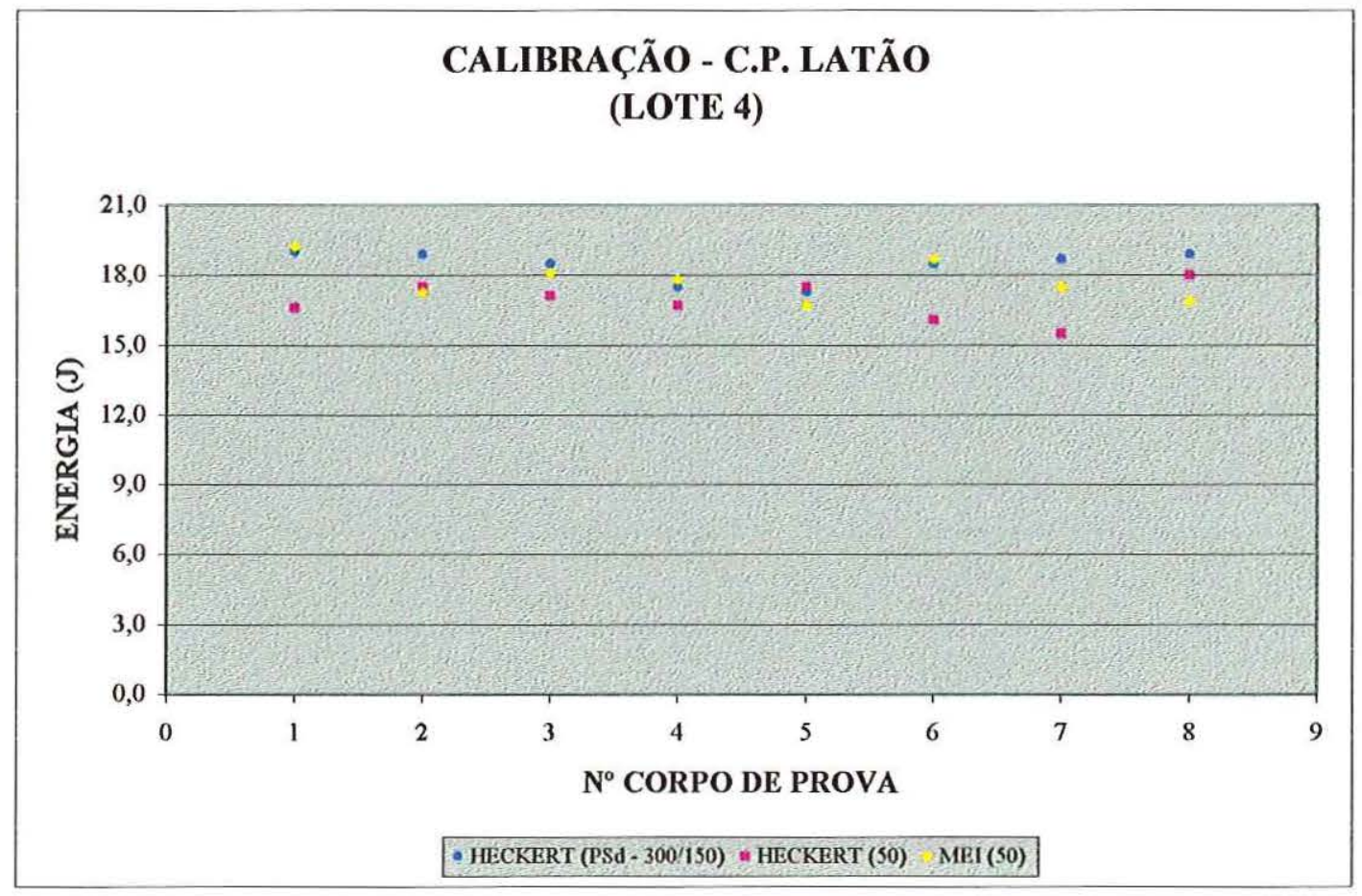

FIGURA B.10 - Gráfico de calibração da máquina de impacto utilizando corpos de prova em latão, referente à TABELA B.10. 
TABELA B.11 - Valores das energias absorvidas medidas nos ensaios de impacto do Lote 5 de corpos de prova em latão.

\begin{tabular}{cccc}
\hline & HECKERT - PSd 300/150 & HECKERT - 50 & MEI - 50 \\
\hline & Energia Absorvida (J) & Energia Absorvida (J) & Energia Absorvida (J) \\
1 & 19,0 & 16,6 & 18,2 \\
2 & 18,9 & 17,5 & 18,5 \\
3 & 18,5 & 17,1 & 17,2 \\
4 & 17,5 & 16,7 & 19,1 \\
5 & 17,3 & 17,5 & 17,9 \\
6 & 18,5 & 16,1 & 18,5 \\
7 & 18,7 & 15,5 & 16,8 \\
8 & 18,9 & 18,0 & 17,1 \\
\hline Média & 18,41 & 16,88 & 17,91 \\
D.P. & 0,65 & 0,82 & 0,81 \\
\hline
\end{tabular}

D. P. $\rightarrow$ Desvio Padrão

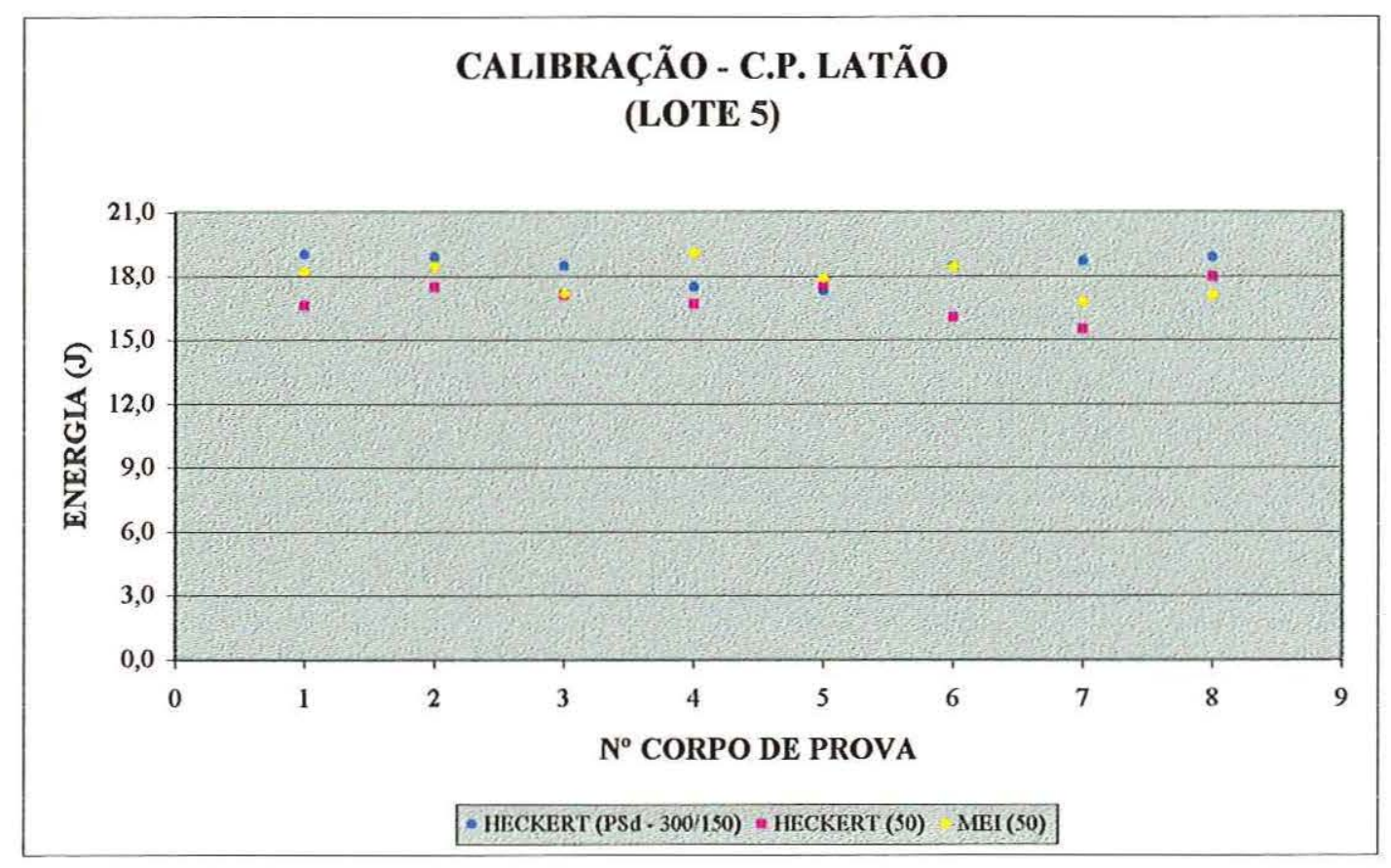

FIGURA B.11 - Gráfico de calibração da máquina de impacto utilizando corpos de prova em latão, referente à TABELA B.11. 
TABELA B.12 - Valores das energias absorvidas medidas nos ensaios de impacto do Lote 6 de corpos de prova em latão.

\begin{tabular}{cccc}
\hline & HECKERT - PSd 300/150 & HECKERT - 50 & MEI - 50 \\
\hline & Energia Absorvida (J) & Energia Absorvida (J) & Energia Absorvida (J) \\
1 & 19,0 & 16,6 & 17,5 \\
2 & 18,9 & 17,5 & 18,1 \\
3 & 18,5 & 17,1 & 16,7 \\
4 & 17,5 & 16,7 & 18,3 \\
5 & 17,3 & 17,5 & 18,5 \\
6 & 18,5 & 16,1 & 17,5 \\
7 & 18,7 & 15,5 & 17,8 \\
8 & 18,9 & 18,0 & 19,1 \\
\hline Média & 18,41 & 16,88 & 17,94 \\
D.P. & 0,65 & 0,82 & 0,73 \\
\hline
\end{tabular}

D. P. $\rightarrow$ Desvio Padrão

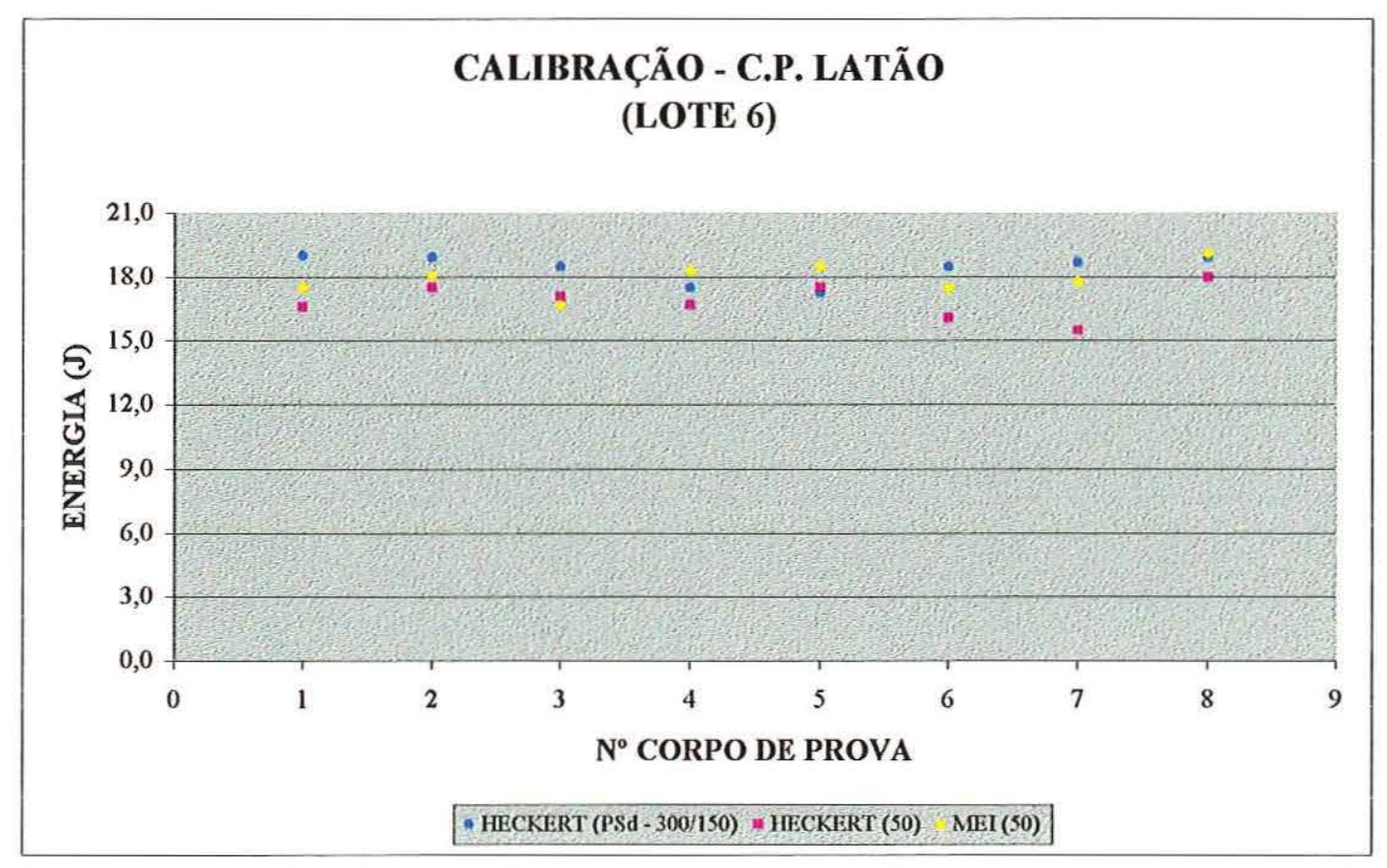

FIGURA B.12 - Gráfico de calibração da máquina de impacto utilizando corpos de prova em latão, referente à TABELA B. 12 . 


\section{REFERÊNCIAS BIBLIOGRÁFICAS}

BEER, F. P.; JOHNSTON Jr., E. R. (1989). Resistência dos materiais. 2.ed. São Paulo, McGraw-Hill.

BIRD, F.; BECKER, H. (1966). Report No. ARA 322-2. Allied Research Associates, Concord, Massachusetts. Resumo em LIEBOWITZ, H. (1972). Fracture - An Advanced Treatise, v. VII. New York and London, Academic Press. Cap. III, p.789-801.

BONFIELD, W.; LI, C.H. (1966). Deformation and fracture of bone. J. appl. Phys., v. 37, p. 869-875.

BURSTEIN, A. H.; REILlY, D. T.; MARTENS, M. (1976). Aging of bone tissue: Mechanical properties. J. Bone Jt. Surg. (A), v.58, p.82-86.

CHIAVERINI,V. (1977). Tecnologia mecânica vol. I - Estrutura, propriedades e processos de fabricação. São Paulo, McGraw-Hill.

COURTNEY, A. C.; WACHTEL, E. F.; MYERS, E. R.; HAYES, W. C. (1995). Age-related reductions in the strength of the femur tested in a fall-loading configuration. $J$ Bone $J$. Surg.(A), v.77, p.387.

CURREY, J. D. (1979). Changes in the impact energy absorption of bone with age. $J$. Biomechanics, v.12, p.459-469.

CURREY, J. D.; BUTLER, G. (1975). The mechanical properties of bone tissue in children. J. Bone Jt. Surg.(A), v.57, p.819-914.

EUROPEAN STANDARD (1992). EN 10 045-1 - Charpy impact tests on metallic materials - Part 1: Test method. Bruxelas.

EUROPEAN STANDARD (1992). EN 10 045-2 - Charpy impact tests - Part 2: Verification of the testing machine (pendulum impact). Bruxelas.

EVANS, F.G. (1973). Mechanical Properties of Bone. Thomas, Springfield. I.L. Resumo em BONFIELD, W.; DATTA, P. K. (1976). Fracture toughness of compact bone. $J$. Biomechanics, v. 9, p.131-134.

HERT, J.; KUCERA, P.; VÁVRA, M.; VOLENÍK, V. (1965). Comparison of the mechanical properties of both the primary and Haversian bone tissue. Acta anat. v.61, p.412-423.

HORATH, L. (1995). Fundamentals of materials science for technologists - Properties, testing, and laboratory exercises. New Jersey, Prentice Hall., p. 355-360.

KNETS, I.V.; PFAFROD, G.O.; SAULGOZIS, J.Z. (1980) - Deformation of hard biological tissue. Zinatne, Riga./Resumo em MÜLLER, M.E., ALLGÖWER, M.; SCHNEIDER, R.; WILLENEGGER, H. (1993). Manual of internal fixation - techniques recommended by AO-ASIF group. Springer-Verlag. 
MARIN, J. (1962). Mechanical Behavior of Engineering Materials. New Jersey, PrenticeHall, p. 237-271.

McELHANEY, J. H. (1966). Dynamic response of bone and muscle tissue. J. appl. Physiol. v.21, p.1231-1236.

MOYLE, D. D.; BOWDEN, R. W. (1984). Fracture of human femoral bone. $J$. Biomechanics v.17, n.3, p.203-213.

MOYLE, D. D.; WELBORN III, J. W; COOKE, F. W. (1978). Work to fracture of canine femoral bone. J. Biomechanics v.11, p.435-440.

MÜLLER, M.E., ALLGÖWER, M.; SCHNEIDER, R.; WILLENEGGER, H. (1993). Manual of internal fixation - techniques recommended by AO-ASIF group. SpringerVerlag.

POPE, M.H.; OUTWATER, J.O. (1972). The fracture characteristics of bone substance. $J$. Biomechanics, v. 5, p. 457-465.

RADIN, E.L.; PAUL, I.L. (1970). Does cartilage compliance reduce skeletal impact loads? Arth. Rheum., v.30, p.139.

RADIN, E. L.; PAUL, I. L. (1971). Importance of bone in sparing articular cartilage from impact. Clin. Orthop., v.78, p.342-344.

SOUZA, A. S. (1974). Ensaios mecânicos de materiais metálicos. 3. ed. São Paulo, Edgard Blücher, p.99-109.

TATTERSAL, H. G.; TAPIN, G. (1966). The work of fracture and its measurements in metals, ceramics and other materials. J. Mater. Sci. v.1, p.296-301.

TIMOSHENKO, S. P. (1982). Resistência dos materiais vol. I. Rio de Janeiro, Livros Técnicos e Científicos.

TIPLER, P. A. (1978). Física vol.I. Rio de Janeiro, Guanabara Dois.

VIANNO, D. C.; STALNAKER, R. L. (1980). Mechanisms of femoral frature. J. Biomechanics, v.13, p.701-715.

YAMADA, H.; EVANS, F.G. (1970). Strength of biological materials. Williams and Wilkins, Baltimore. Resumo em MÜLLER, M.E., ALLGÖWER, M.; SCHNEIDER, R.; WILLENEGGER, H. (1993). Manual of internal fixation - techniques recommended by AO-ASIF group. Springer-Verlag. 